ENTREPRENEURSHIP AND SUSTAINABILITY ISSUES

ISSN 2345-0282 (online) http://jssidoi.org/jesi/

2020 Volume 8 Number 2 (December)

http://doi.org/10.9770/jesi.2020.8.2(37)
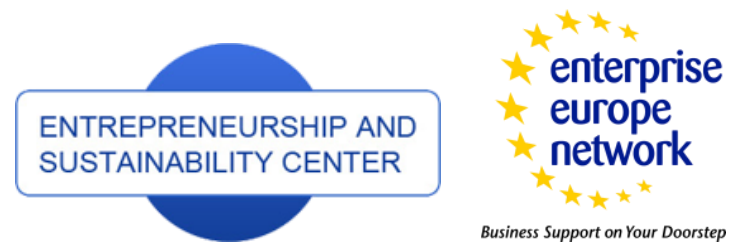

Business Support on Your Doorstep
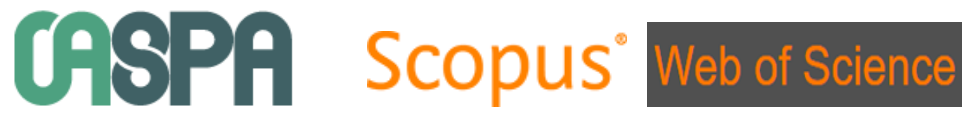

http://jssidoi.org/esc/home

\title{
Clarivate
Analytics \\ THE REMITTANCE INFLOWS IN VISEGRAD COUNTRIES: A SOURCE OF ECONOMIC GROWTH, OR MIGRATION POLICY MISTING?*
}

\author{
Ladislav Kabat ${ }^{1}$, Lubos Cibak $^{2}$, Stanislav Filip ${ }^{3}$ \\ 1,2,3 University of Economics and Public Administration Management in Bratislava, Furdekova 16, 85104 Bratislava, \\ Slovak Republic \\ E-mails:I ladislav.kabat@vsemvs.sk ; ${ }^{2}$ lubos.cibak@vsemvs.sk ; ${ }^{3}$ stanislav.filip@vsemvs.sk
}

Received 15 July 2020; accepted 10 September 2020; published 30 December 2020

\begin{abstract}
The global economy and worldwide open market of goods and services creates a favorable environment for expanding technological cooperation among countries. However, such development is also accompanied by an intense movement of the labor force. After opening the EU single market, a large number of foreign workers from the new member countries found the better paying jobs in the highly developed EU countries. The total volume of this financial compensation that was transferred into mother countries was more than USD 70 billion in 2017. A primary question for this situation is the role that these financial sources play in the economies of the mother countries. Have the transferred money contributed to economic growth or have they been materialized in the sphere of private household consumption? Our paper answers these questions in the case of the Visegrad (V4) countries. The scientific literature does not offer a unified position in this respect. The positive, neutral, and negative impacts on concerned economies are presented. In our view, the answers should be verified in the specific conditions of the beneficiary countries, taking into account all the statistically relevant factors. The primary source of our information is statistical data of international organizations, particularly of the United Nations (UN), the World Bank, the Organization for Economic Cooperation and Development (OECD), the European Union, and the International Organization for Migration. As a tool for solution was applied the analysis of panel data.
\end{abstract}

Keywords: foreign direct investment; portfolio investment; economic growth; GDP; unemployment; regional development

Reference to this paper should be made as follows: Kabat, L., Cibak, L., Filip, S. 2020. The remittance inflows in VISEGRAD countries: a source of economic growth, or migration policy misting. Entrepreneurship and Sustainability Issues, 8(2), 606-628. http://doi.org/10.9770/jesi.2020.8.2(37)

JEL Classifications: O150, J610, J620, Z130, F24

\footnotetext{
* The paper is the output of a scientific project IGA 3/2019 „, Creation of a mechanism for the purposes of migration to the social and economic development of the territory" (Funder: VSEMvs IGA VSEMvs, i.e. School of Economics and Management in Public Administration)
} 


\section{ENTREPRENEURSHIP AND SUSTAINABILITY ISSUES}

ISSN 2345-0282 (online) http://jssidoi.org/jesi/

2020 Volume 8 Number 2 (December)

http://doi.org/10.9770/jesi.2020.8.2(37)

Make your research more visible, join the Twitter account of ENTREPRENEURSHIP AND SUSTAINABILITY ISSUES: @Entrepr69728810

\section{Introduction}

The global economy and worldwide open market create a favorable environment for expanding technological cooperation among countries. However, such development is also accompanied by an intense movement of the labor force. Consequently, the flow of financial remittances paid to the foreign labor force became an interesting topic for research and scientific studies. The cardinal question is whether the remittances received by an individual country have an impact on the country's GDP growth.

After the opening of the EU single market, a large number of foreign workers from the new EU member countries found better paying positions in the highly developed EU countries. The total volume of such financial compensation transferred was more than USD 70 billion in 2017. According to valid data on the labor force movements, the large share of these financial means was transferred into the new EU member countries.

Faced with this situation, we raise the following question: what role did these financial sources play in the economies of the mother countries? Did these financial sources contribute to economic growth, or had they been materialized in the sphere of private household consumption?

Searching for the generally accepted answer is not an easy task, having in mind the large differences in volume of remittances transferred, the level of economic and social development in the receiving countries, the quality of transferring institutions and of the entrepreneurial environment, and the possibilities for investment of the external finances in the mother countries.

The main objective of this article is to verify the hypothesis on the impact of the remittance inflows on economic growth in the mother countries. For verification of the above hypothesis, we used econometric modelling, particularly the panel data analysis and Granger causality testing. The countries included in the study are the Visegrad Group (V4) countries: the Czech Republic, Hungary, Poland, and Slovakia.

We also use statistical data collected and processed by selected international organizations, particularly the United Nations, the World Bank, the Organization for Economic Cooperation and Development (OECD), the European Union (EU), and the International Organization for Migration (IOM).

\section{Review of literature: migration and migrants}

International migration, or the movement of people across the borders of countries, has historically occurred since ancient times and has happened for different reasons. While international migration has always had a major impact on the socio-economic environment or poverty alleviation in the countries of origin, it has also made an impact on the social and demographic structure of the targeted countries. Migration has influenced not only the economic but also the social and demographic environment of both host and parent countries.

The migration of humanity constitutes a special socio-demographic movement and has different forms, scopes, and durations as well as a considerably long history in virtually all parts of the world (www.historyworld.net). More recently, migration has been in the spotlight of the media and the professional public, as presented by Pooley (2019) and Hoerder. (2017) 


\section{ENTREPRENEURSHIP AND SUSTAINABILITY ISSUES}

ISSN 2345-0282 (online) http://jssidoi.org/jesi/

2020 Volume 8 Number 2 (December)

http://doi.org/10.9770/jesi.2020.8.2(37)

Make your research more visible, join the Twitter account of ENTREPRENEURSHIP AND SUSTAINABILITY ISSUES: @Entrepr69728810

According to Demirguc-Kunt (2019), the high degree of globalization in international and regional economies is one of the key factors that enhances interregional migration flows. Persistent differences in the income levels of the population as well as national and regional unrest and conflicts of war are also classified among the promigration factors.

Available statistics from the International Organization for Migration indicate that currently some 271 million people are living outside of their mother countries, which represents approximately $3.5 \%$ of the global population. More detailed statistical information on the reasons for this situation are found according to individual migration segments, including migrants, expatriates, clandestine migrants, immigrants, people who temporarily resettle, asylum seekers, and refugees, IMO (2020). However, the accuracy of statistics on migration flows, as highlighted by Alvarez (2015), is problematic to estimate.

The movements of residents from the mother country to the host country are referred to as migratory waves and are identified as immigration and emigration. The first case is represented by the "inflow" of people to the host country, and the latter case represents the "outflow" of residents from the parent country. The reasons for these movements may vary, as presented and analyzed by Castelli (2018); Consumer (2020); Filipek (2019); Hendricks (2019).

Generally, the migrants who leave the mother country tend to look for an opportunity to improve their personal and family economic and social situation. These migrants are classified as economic migrants. The main objectives of their migratory movement are mostly to seek countries with a higher level of economic development, a higher standard of living, and the possibility of an official access to the labor market as well as subsequently to achieve full incorporation into the social environment of the new country Kováč,M.(2015), Vaysilova (2019). Globally, approximately 266 million migrants are currently statistically classified as economic migrants. Most of them have the opportunity to enter the labor market and to obtain the officially reported salary as a domestic labor force. The financial compensation of these migrants, after transferring to the home countries is known as remittances World Bank (2016),

Extensive information sources confirm that migrants are an important factor in the host country's economy. According Kosten (2018), "the migrants play a crucial role in the U.S.A. labor force". The study of the University of Pennsylvania (2016) also confirms the importance of "the active participation of migrants in technical innovation and intellectual creativity in various academic and research fields across the US economy."

According to UN Secretary-General A. Guterres (2018), "the managed migration is one of the most challenging but also a promising social movement and opportunity for enhancing the international cooperation across the industrial and developing countries."

\section{Migration remittances: what do they bring our countries?}

Evidence of the active participation of migrants in the economic development of host countries is found in the increasing volume of remittances that are directly related to their labor activity. According the World Bank (2019), the volume of remittances transferred to the mother countries in 2018 was over USD 689 billion, whereby USD 529 billion (76\%) was transferred to beneficiaries in low-income developing countries. The high volume of reported financial transfers "become over time one of the important external sources of their economic growth". Similar conclusions are presented by other sources World Bank (2016), OECD (2020). 


\section{ENTREPRENEURSHIP AND SUSTAINABILITY ISSUES}

ISSN 2345-0282 (online) http://jssidoi.org/jesi/

2020 Volume 8 Number 2 (December)

http://doi.org/10.9770/jesi.2020.8.2(37)

Make your research more visible, join the Twitter account of ENTREPRENEURSHIP AND SUSTAINABILITY ISSUES: @Entrepr69728810

The published outputs indicate a wide range of the assessed impact of remittances on the economies of the mother countries, ranging from a highly positive evaluation to the lack of any impact. Some articles even identified remittances as "corruption inhibitors", and therefore, they should be classified as a negative factor in the economic environment.

In this article, we specifically address the impact of migrant remittances on the economies of the Visegrad Group (V4) countries. We compare the volume and economic efficiency of the received remittances in these countries with the results of selected studies for another countries. We also present the various positions on the evaluation of the role of remittances in the economic growth of selected countries.

Meyer and Sherab (2016) have studied the impact of remittances on economic growth using the panel data approach to assess six remittance-receiving Balkan countries during the period 1999-2013. Their final analysis confirmed that remittances have a positive impact on economic growth in mother countries.

According to Nita (2016) "the remittances in Romania also have a positive impact on the economic development of this country." A similar position about Romania's experience is presented by Comes (2018) et al.. Simonescu (2019) demonstrates a more complex evaluation of remittances that indicates both positive and negative aspects of migration flows in the context of Romanian membership to the EU. According to Cismas et al., "the hypothesis that remittances has a significant influence on the Romanian economy was not validated, and the statistical data does not show a long-run neither a short-run influence or a Granger causality.“

A slightly similar conclusion is presented by Rauser et al. (2018) who posit that the remittances have a positive impact on the economic development in Lithuania, Latvia, and Estonia.

A certain level of skepticism in the evaluation of the remittances impact is also presented by Sobiech (2019) who found that "remittances can foster growth, but the effect is significant only at low levels of financial development of the individual country." In line with many other authors, he also believes that the remittances play an important role in alleviating poverty at the household level.

The role of remittances in securing the durability of economic growth in developing countries was studied by Adams Mensah Klobodu (2016). He found that remittance do not have a robust impact on the economic growth in Sub-Saharan African countries. However, as a byproduct of his study, he identified the so-called "institutional linkages" of remittances, meaning that the growth effect of remittances is enhanced by a stable and democratic government. Another conclusion is offered by Coulibaly (2015) who notes that no strong evidence exists to support the view that remittances promote financial development in Sub-Saharan African countries.

A strong position on the short-term and long-term effects of remittances is offered by Barajas et al (2010). Their study relies on the analysis of the development of remittance flows between 1970 and 2004 for 84 countries. According to these authors, the remittances have poverty-alleviating and consumption-smoothing effects on recipient households. Furthermore, Azam (2016) highlights that migration and remittances have first-order effects on poverty. This finding is based on a study representing 39 countries of high-, middle-, and low-income countries across the world.

A more cautious stance in evaluating the effectiveness of remittances is upheld by Clemens (2016). Similarly, according to Chami et al.(2018), "remittances are essential to fight poverty, but they failed to identify the remittances' impact on economic growth". The authors also identified the accompanying negative effects of 


\section{ENTREPRENEURSHIP AND SUSTAINABILITY ISSUES}

ISSN 2345-0282 (online) http://jssidoi.org/jesi/

2020 Volume 8 Number 2 (December)

http://doi.org/10.9770/jesi.2020.8.2(37)

Make your research more visible, join the Twitter account of ENTREPRENEURSHIP AND SUSTAINABILITY ISSUES: @Entrepr69728810

remittances, which often "contributes to weakening the entrepreneurial activity of young people, relying on external sources" which means accepting the downsides of the "Dutch disease."

Several authors from developing countries have made valuable findings on the negative phenomena identified in the analysis of the remittance flows. Specifically, these studies have mentioned the phenomenon of corruption, which has been identified as an endogenous factor at various levels of the economic implementation of remittances. Muhhamad and Khairuzzaman (2013) have examined this problem through a data base for five countries of South and Southeast Asia for the period 1985-2011. Applying the econometric model, they "found the positive and statistically significant effects of FDI and workers remittances on economic growth"; however, the empirical results simultaneously demonstrate the negative and statistically significant impact of endemic corruption on economic growth.

An exact analysis of remittances and corruption was studied on panel data from 122 countries by Majeed (2016), who identified that "among the least corrupt countries, remittances do not appear to increase corruption but, among the most corrupt countries, it significantly contributes to growth of corruption behavior." These findings are quite understandable and could help to assess situation for the majority of central European countries as well. An in-depth study on remittances and corruption was conducted with data from 127 countries by Tyburski (2014), who adopted the political economy methodology to analyze these two phenomena. He found that democratic institutions significantly reduce the probability that remittances increase corruption and that democracies tend to control corruption better than nondemocratic regimes. According the author, "the remittances should be considered as a curse but also as a cure for corruption." Another strong position about the outcome of remittance inflows is presented by Berdiev et al.(2013), who have also identified the existence of a negative institutional impact.

The fact that the published results evidently indicate a wide range of unsolved problems related to the inflow and outflow of remittances is important to underline. In particular, many articles draw attention to the ambiguous impact on the economies of the beneficiary countries. We follow this position when presenting our results.

\section{Are there real causal relations between remittances and economic growth?}

Furthermore, the published scientific findings that are unsure about making direct causal links between correlated variables deserve greater attention. Aldrich (2018) presents various scenarios of the inappropriate and incorrect application of the methods of correlation and regression analysis. The findings highlight the repeated errors in the methodologies of research projects and publications by arguing that "...correlation alone cannot be used as evidence for a causal-and-effect relationship between a treatment and benefit, a risk factor and a disease, or a social or economic factor and various outcomes."

An important position is presented by Kahn (2018), who notes that "causal effects are difficult to quantify because we rarely observe occasions, where one variable is changed while others are constant." Such methodological weakness have also been studied by Bleske-Rechek (2015) who underlined that little systematic data is available to the extent that individuals conflate correlation with causation. She also found that people frequently tend to draw causal outcomes from non-causal data, regardless of the statistical findings.

An noteworthy study of the correlation and causality phenomena is offered by Panizza and Presbytero (2014). They studied if public debt has a causal effect on GDP growth in OECD countries. According their findings, a 
ENTREPRENEURSHIP AND SUSTAINABILITY ISSUES

ISSN 2345-0282 (online) http://jssidoi.org/jesi/

2020 Volume 8 Number 2 (December)

http://doi.org/10.9770/jesi.2020.8.2(37)

Make your research more visible, join the Twitter account of ENTREPRENEURSHIP AND SUSTAINABILITY ISSUES: @Entrepr69728810

negative correlation exists between debt and growth. However, the link between debt and growth disappears after the researchers corrected the model for endogeneity.

The highly qualified approach to the problem of identification and differentiation between correlation and causal relationships has also been developed in biological science, as presented by Berwick (2017).

In conclusion, finding answers to questions about the impact of remittance payments on the volume or the growth of GDP and GDP per capita is more complex than it appears at first glance in light of the studies previously presented. To respond to the research topic properly, extending the model instruments in such a way as to eliminate the incorrect interpretations of correlation and causal relations is necessary.

\section{Objectives of the article}

The dynamic of migration movements in Czechia, Hungary, Poland, and Slovakia are the subject of sharp political and expert discussions in these countries. In particular, the financial flows that represent compensation are closely monitored for migrant workers who operate abroad outside of their parent country. Given that these financial flows are mainly directed from industrialized countries to countries with a lower level of economic potential, they are analyzed not only in terms of their volume but also in terms of their potential impact on the dynamics of the economy of the parent countries whose citizens are the beneficiaries of these means. For many countries, the volume is comparable to the volume of external financial resources such as the official development assistance (e.g., Official Development Aid or ODA) and direct foreign investment (e.g., Foreign Direct Investment or FDI). Therefore, the question under investigation is whether these resources have a positive impact on the dynamics of the growth of the national economy, namely the economies of the countries to which the remittances are directed.

Based on the literature, we segmented the arguments and conclusions into the following groups:

1. Tne first group of authors presents conclusions on the clear positive impact of remittances on the economic growth of the beneficiary countries. These positions are based on model projections, in which the volume of remittances is identified as one of the statistically significant explanatory variables.

2. Based on similar model instruments, another group of authors offers more cautious conclusions on impact of remittances on GDPpc. The effect of remittances is presented as accompanying phenomenon with the other development assistance sources. Also, the statistical significance of the REMIN confirm to this conclusion.

3. Another group of authors rejects the general conclusions on the positive impact of remittance on economic growth of the beneficiary countries. These authors, based on more sophisticated modelling analyses, highlight the negative effects on the corruption environment which is detrimental to the home economies. Important warnings exist also about the insufficient verification of the causal effects of remittance on economic growth.

4. Interesting results are presented by authors who highlight the institutional aspects of the environment in which remittance inflows are materialized. The quality and efficiency of relevant government institutions and their democratically functioning structures and processes are pointed.

The main objective of our paper is to verify the remittance inflows and other relevant factors in terms of their impact on economic growth of the V4 countries. We have used model tools and information sources that have been applied in the majority of published and analyzed articles. Adopting this approach, we intend to eliminate the impact of different methodologies in quantitative analysis and to increase the comparative weight of our results. 
Make your research more visible, join the Twitter account of ENTREPRENEURSHIP AND SUSTAINABILITY ISSUES: @Entrepr69728810

\section{Methodological framework}

The impact of remittance inflows and other selected factors on economic dynamics is estimated through the GDP per capita volume and the GDP per capita growth.

The general econometric model on basis of which we analyze the dependency in question takes the form of the following:

$\mathrm{Yi}=\alpha+\sum_{j=1}^{n} \beta i X i+\mathrm{u}=\alpha+\beta 1 * \mathrm{X} 1+\beta 2 * \mathrm{X} 2, \ldots, \beta \mathrm{n} * \mathrm{Xn}+\mathrm{u}$

where $\mathbf{Y}$ is the studied dependent variable, $\boldsymbol{\alpha}, \boldsymbol{\beta 1}, \ldots, \boldsymbol{\beta n}$ are the regression coefficients, and $\mathbf{u}$ is the expected estimation error.

Model (1) is analyzed in two alternatives, where variable $\mathbf{Y}$ presents the following:

- Alternative A-Volume of GDP per capita

labelled as GDPpc

- Alternative B-Annual growth of GDP per capita

labelled as GDPpc-G

As explanatory factors, or independent variables, according to earlier conducted theoretical studies and experimental recounts, we have defined the following:

$$
\text { Factors }
$$

1. Volume of inflowed remittances as \% GDP

2. Volume of inflowed remittances-lagged as \% GDP

3. Volume of outflows of remittance as $\%$ GDP

4. Export as \% GDP

5. Import as \% GDP

6. Direct foreign investment as \% GDP

7. Total capital formation as $\%$ GDP

8. Total volume of final consumption as \% GDP

9. Volume of international trade as \% GDP

10. Population growth in $\%$ annually

11. Government debt as \% GDP
Variable

- REMIN

- REMOUT X2

- EXPORT X3

- IMPORT X4

- FDI X5

- GCF X6

- FINCONSUMX7

- TRADE X8

- POPUL-G X9

- DEBT $\quad \mathrm{X} 10$

To eliminate the heteroscedasticity in values of dependent variables, we have used their log transformed values as follows:
- GDPpc
- new value
- LN(GDPpc)

The values of all explanatory variables are applied in their relative values toward the national GDP.

The values reflecting annual growth of GDPpc-G are presented in their relative values (\%) toward the previous year.

The relevant statistical information for the V4 countries for period 2000-2018 is transformed into panel data, in which the specificities of each country are represented by sectoral, time invariant variables labelled as Czechia, Hungary, Poland, and Slovakia. 
Make your research more visible, join the Twitter account of ENTREPRENEURSHIP AND SUSTAINABILITY ISSUES: @Entrepr69728810

On basis of an analysis of previous economic developments, the significant impact of the economic recession on individual national economies has been identified in the countries concerned in 2009 and 2010. To quantify this impact, we expanded the list of time invariant explanatory variables labelled as Crisis09 and Crisis 10.

Having in mind the above presented clarification, the econometric model for estimating the theoretical values of the statistically dependent variable LN(GDPpc) and GDPpc-G has the following form:

\section{For dependent variable LN(GDPpc):}

LN $($ GDPpc $)=b 1 *$ REMIN + b2*REMIN $-1+b 3 *$ REMOUT + b4*EXPORT + b5*IMPORT + b6*FDI

$+\mathrm{b} 7 *$ GCF + b8*FINCOMSUM + b9*TRADE + b10*POPUL + b11*DEBT + u

\section{For dependent variable GDPpc-G:}

GDPpc-G = b1*REMIN + b2*REMIN-1 + b3*REMOUT + b4*EXPORT + b5*IMPORT + b6*FDI

$+\mathrm{b} 7 * \mathrm{GCF}+\mathrm{b} 8 *$ FINCOMSUM + b9*TRADE + b10*POPUL + b11*DEBT + u

Consequently, we verified the applicability of both models to estimate the impact of remittance flows on macroeconomic indicators $\mathrm{LN}(\mathrm{GDPpc})$ and GDPpc-G. This means that we should verify the validity of the following hypotheses:

H1: Variable REMIN has a statistically significant impact on LN(GDPpc)

H2: Variable REMIN has a statistically significant impact on GDPpc-G

As a methodological tool to answer the above presented hypotheses, we applied the pooled regression models with the fixed effects.

As a final test for evaluating the impact of remittance inflows on economic growth, the Granger causality test was employed. According the EViews approach, this test is based on bivariate regression of the following form:

$$
\begin{array}{ll}
\mathrm{LN}(\mathrm{GDPpc}) \mathrm{t} & =\mathrm{Yt}=\alpha \mathrm{o}+\alpha 1 * \mathrm{Yt}-1+\ldots+\alpha 1^{*} \mathrm{Yt}-1+\beta 1 * \mathrm{Xt}-1+\ldots+\beta 1 * \mathrm{Xt}-1+\mathrm{ut} \\
\mathrm{REMINt} & =\mathrm{Xt}=\alpha \mathrm{o}+\alpha 1 * \mathrm{Xt}-1+\ldots+\alpha 1^{*} \mathrm{Xt}-1+\beta 1 * \mathrm{Yt}-1+\ldots+\beta 1 * \mathrm{Yt}-1+\mathrm{ut}
\end{array}
$$

where Yt and Xt correspond to variables LN(GDPpc)t and REMINt .

In the above formulated model (4), the Xt (REMIN) does not Grenger-cause Yt (GDPpc) only if all $\beta \mathrm{j}=0$. Reciprocally, in model (5), the Yt (GDPpc) does not Grenger-cause Xt (REMIN) only if all $\beta \mathrm{j}=0$.

Testing procedure was performed by EViews software package.

\section{Data, results, and discussion}

All input data are drawn from the World Bank, the International Organization for Migration, Eurostat, and the UN OpenData sources. The time series data of the relevant indicators for the 2000-2018 period is presented in Table 1. 


\section{ENTREPRENEURSHIP AND SUSTAINABILITY ISSUES}

ISSN 2345-0282 (online) http://jssidoi.org/jesi/ 2020 Volume 8 Number 2 (December) http://doi.org/10.9770/jesi.2020.8.2(37)

Make your research more visible, join the Twitter account of ENTREPRENEURSHIP AND SUSTAINABILITY ISSUES: @Entrepr69728810

Table 1 Original data for Czechia, Hungary, Poland and Slovakia for 2000-2018

\begin{tabular}{|c|c|c|c|c|c|c|c|c|c|c|c|c|}
\hline \multicolumn{13}{|c|}{ Original input data } \\
\hline LN(GDP) & LN(GDPP & DPpc G & REM-IN & REM-OUT & \begin{tabular}{|l|} 
Export \\
\% GDP \\
\end{tabular} & \begin{tabular}{|l|} 
Import \\
\% GDP \\
\end{tabular} & \begin{tabular}{|c|} 
FDI \\
\% GDP
\end{tabular} & \begin{tabular}{|l|} 
GCForm \\
$\%$ GDP
\end{tabular} & $\begin{array}{c}\text { FCONSUMP } \\
\% \text { GDP }\end{array}$ & \begin{tabular}{|l|} 
TRADE \\
$\%$ GDP \\
\end{tabular} & \begin{tabular}{|c|} 
POPUL \\
$\%$ Growth
\end{tabular} & \begin{tabular}{|c|} 
DEBT \\
$\%$ GDP
\end{tabular} \\
\hline 11,89 & 9,56 & 4,56 & 0,48 & 0,36 & 48,19 & 50,04 & 45,50 & 31,41 & 50,57 & 88,32 & $-0,28$ & 17,00 \\
\hline 11,96 & 9,63 & 3,30 & 0,38 & 0,40 & 49,03 & 50,28 & 47,54 & 31,55 & 49,88 & 94,81 & $-0,38$ & 22,80 \\
\hline 11,98 & 9,66 & 1,85 & 0,41 & 0,48 & 45,12 & 46,40 & 48,26 & 30,13 & 49,86 & 95,50 & $-0,19$ & 25,90 \\
\hline 12,03 & 9,71 & 3,63 & 0,50 & 0,56 & 46,91 & 48,11 & 50,00 & 29,04 & 49,90 & 96,49 & $-0,03$ & 28,30 \\
\hline 12,10 & 9,78 & 4,87 & 1,03 & 0,68 & 57,34 & 56,53 & 52,30 & 29,35 & 48,86 & 95,44 & 0,03 & 28,50 \\
\hline 12,16 & 9,83 & 6,39 & 0,98 & 0,60 & 62,18 & 59,83 & 44,51 & 29,12 & 47,85 & 95,67 & 0,14 & 27,90 \\
\hline 12,21 & 9,88 & 6,56 & 1,03 & 0,69 & 65,19 & 62,45 & 51,35 & 30,04 & 46,97 & 96,04 & 0,27 & 27,70 \\
\hline 12,31 & 9,98 & 4,99 & 0,97 & 0,85 & 66,41 & 63,96 & 59,40 & 32,07 & 46,06 & 94,96 & 0,58 & 27,50 \\
\hline 12,34 & 9,99 & 1,83 & 0,48 & $\mathbf{0 , 8 9}$ & 63,23 & 61,06 & 48,01 & 31,06 & 47,37 & 94,15 & 0,57 & 28,30 \\
\hline 12,30 & 9,95 & $-5,34$ & 0,58 & 0,71 & 58,68 & 54,81 & 61,03 & 26,51 & 48,61 & 93,85 & 0,57 & 33,60 \\
\hline 12,31 & 9,96 & 1,98 & 0,59 & 0,52 & 66,03 & 62,94 & 61,94 & 27,12 & 48,96 & 94,66 & 0,29 & 37,40 \\
\hline 12,34 & 9,99 & 1,57 & 0,61 & 0,50 & 71,31 & 67,48 & 52,89 & 26,96 & 49,05 & 95,80 & 0,21 & 39,80 \\
\hline 12,35 & 10,00 & $-0,94$ & 0,68 & 0,44 & 76,17 & 71,37 & 65,82 & 26,19 & 49,21 & 96,79 & 0,14 & 44,50 \\
\hline 12,37 & 10,02 & $-0,52$ & 0,83 & 0,34 & 76,87 & 71,11 & 64,03 & 24,67 & 49,41 & 104,00 & 0,03 & 44,90 \\
\hline 12,43 & 10,08 & 2,61 & 1,26 & 0,45 & 82,55 & 76,18 & 58,47 & 25,88 & 48,07 & 104,70 & 0,11 & 42,20 \\
\hline 12,50 & 10,14 & 5,10 & 1,43 & 0,39 & 81,05 & 75,05 & 62,42 & 27,96 & 46,83 & \begin{tabular}{|l|}
105,09 \\
\end{tabular} & 0,20 & 40,00 \\
\hline 12,51 & 10,15 & 2,25 & 1,60 & 0,45 & 79,56 & 71,84 & 62,46 & 25,98 & 47,04 & \begin{tabular}{|l|}
104,63 \\
\end{tabular} & 0,19 & 36,80 \\
\hline 12,56 & 10,20 & 4,08 & 1,66 & 0,51 & 79,73 & 72,20 & 72,25 & 25,87 & 47,42 & 103,49 & 0,27 & 34,70 \\
\hline 12,60 & 10,24 & 2,65 & 1,60 & 0,65 & 78,39 & 72,00 & 66,59 & 26,17 & 47,48 & 103,49 & 0,29 & 32,60 \\
\hline 11,57 & 9,25 & 4,75 & 0,47 & 0,07 & 66,86 & 70,55 & 69,05 & 28,06 & 54,43 & 96,13 & $-0,26$ & 55,00 \\
\hline 11,67 & 9,35 & 4,31 & 0,45 & 0,07 & 64,88 & 66,17 & 69,59 & 26,24 & 53,97 & 98,45 & $-0,23$ & 51,60 \\
\hline 11,75 & 9,43 & 5,04 & 0,34 & 0,07 & 58,14 & 60,18 & 70,08 & 25,60 & 54,58 & 100,09 & $-0,28$ & 54,80 \\
\hline 11,80 & 9,48 & 4,38 & 0,29 & 0,07 & 56,33 & 60,27 & 70,39 & 24,61 & 56,32 & 102,22 & $-0,29$ & 57,40 \\
\hline 11,84 & 9,53 & 5,06 & 1,61 & 0,50 & 59,65 & 63,61 & 70,68 & 26,88 & 55,02 & 95,95 & $-0,22$ & 58,30 \\
\hline 11,89 & 9,58 & 4,45 & 1,69 & 0,53 & 62,64 & 64,95 & 54,06 & 25,32 & 54,82 & 96,26 & $-0,20$ & 60,20 \\
\hline 11,94 & 9,63 & 4,19 & 1,79 & 0,53 & 73,87 & 75,00 & 69,54 & 25,79 & 53,32 & 96,09 & $-0,16$ & 64,40 \\
\hline 11,97 & 9,66 & 0,40 & 1,65 & 0,71 & 77,94 & 77,40 & 68,26 & 24,28 & 54,37 & 96,17 & $-0,15$ & 65,30 \\
\hline 12,01 & 9,71 & 1,24 & 1,59 & 0,73 & 79,28 & 78,92 & 55,75 & 24,62 & 53,62 & 96,04 & $-0,18$ & 71,20 \\
\hline 11,97 & 9,66 & $-6,55$ & 1,34 & 0,58 & 74,40 & 70,37 & 75,73 & 20,26 & 53,63 & 96,25 & $-0,15$ & 77,50 \\
\hline 12,01 & 9,71 & 0,89 & 1,58 & 0,53 & 81,75 & 76,45 & 69,52 & 20,60 & 52,53 & 97,08 & $-0,23$ & 80,20 \\
\hline 12,06 & 9,76 & 2,11 & 1,97 & 0,52 & 86,59 & 80,47 & 60,81 & 20,39 & 52,78 & 96,80 & $-0,28$ & 80,50 \\
\hline 12,06 & 9,77 & $\begin{array}{r}-0,96 \\
-0,\end{array}$ & 2,75 & 0,47 & 86,32 & 79,55 & 81,65 & 19,33 & 53,83 & 98,06 & $-0,32$ & 78,40 \\
\hline 12,09 & 9,80 & 2,24 & 3,40 & 0,35 & 85,58 & 78,59 & 80,72 & 20,92 & 52,32 & 104,72 & $-0,28$ & 77,10 \\
\hline 12,14 & 9,85 & 4,48 & 3,39 & 0,35 & 87,42 & 81,07 & 71,68 & 23,44 & 50,15 & 104,19 & $-0,27$ & 76,60 \\
\hline 12,19 & 9,90 & 4,09 & 3,72 & 0,26 & 87,98 & 79,99 & 70,08 & 23,30 & 48,90 & 103,03 & $-0,24$ & 76,70 \\
\hline 12,18 & 9,89 & 2,50 & 3,83 & 0,30 & 87,15 & 78,40 & 65,63 & 21,32 & 49,80 & 102,71 & $-0,30$ & 76,00 \\
\hline 12,21 & 9,93 & 4,60 & 3,43 & 0,32 & 87,14 & 79,85 & 66,90 & 22,85 & 49,52 & 103,49 & $-0,27$ & 73,40 \\
\hline 12,27 & 9,99 & 5,30 & 3,08 & 0,34 & 84,94 & 80,57 & 61,12 & 27,23 & 48,70 & 103,49 & $-0,20$ & 70,80 \\
\hline 12,79 & 9,14 & 5,66 & 0,87 & 0,08 & 27,23 & 33,56 & 36,94 & 24,63 & 63,63 & 100,10 & $-0,03$ & 36,40 \\
\hline 12,82 & 9,17 & 1,28 & 0,82 & 0,08 & 27,23 & 30,85 & 37,51 & 20,56 & 64,40 & \begin{tabular}{|l|}
101,63 \\
\end{tabular} & $-0,03$ & 37,10 \\
\hline 12,87 & 9,22 & 2,09 & 0,85 & 0,08 & 28,76 & 32,17 & 38,42 & 18,45 & 66,33 & 103,79 & $-0,05$ & 41,50 \\
\hline 12,89 & 9,25 & 3,63 & 1,05 & 0,07 & 33,39 & 36,05 & 38,95 & 18,83 & 64,92 & 105,70 & $-0,07$ & 46,30 \\
\hline 12,97 & 9,33 & 5,20 & 1,85 & 0,13 & 34,26 & 36,95 & 40,64 & 20,23 & 64,17 & 97,55 & $-0,06$ & 45,10 \\
\hline 13,02 & 9,38 & 3,54 & 2,11 & 0,12 & 34,61 & 35,67 & 28,20 & 19,91 & 62,85 & 99,58 & $-0,04$ & 46,40 \\
\hline 13,08 & 9,43 & 6,25 & 2,46 & 0,12 & 37,86 & 39,93 & 33,59 & 21,70 & 61,89 & 98,65 & $-0,06$ & 46,90 \\
\hline 13,18 & 9,53 & 7,09 & 2,44 & 0,16 & 38,56 & 42,10 & 38,31 & 25,21 & 60,22 & 98,08 & $-0,05$ & 44,20 \\
\hline 13,22 & 9,58 & 4,24 & 1,96 & 0,21 & 37,86 & 42,90 & 27,80 & 24,66 & 61,78 & 97,15 & $\mathbf{0 , 0 1}$ & 46,30 \\
\hline 13,23 & 9,58 & 2,75 & 1,86 & 0,16 & 37,18 & 38,04 & 38,06 & 20,57 & 61,58 & 96,24 & 0,07 & 49,40 \\
\hline 13,33 & 9,67 & 3,90 & 1,60 & 0,16 & 40,06 & 42,05 & 39,14 & 21,31 & 61,57 & 95,94 & $-0,29$ & 53,10 \\
\hline 13,39 & 9,74 & 4,96 & 1,46 & 0,16 & 42,56 & 44,52 & 31,09 & 22,44 & 61,47 & 95,90 & 0,05 & 54,10 \\
\hline 13,44 & 9,79 & 1,61 & 1,40 & 0,17 & 44,44 & 44,88 & 39,76 & 20,99 & 61,52 & 96,21 & 0,00 & 53,70 \\
\hline 13,45 & 9,79 & 1,45 & 1,41 & 0,17 & 46,32 & 44,37 & 43,71 & 18,98 & 60,94 & 107,35 & $-0,06$ & 55,70 \\
\hline 13,48 & 9,84 & 3,40 & 1,36 & 0,22 & 47,57 & 46,13 & 38,86 & 20,36 & 60,02 & \begin{tabular}{|c|}
106,90 \\
\end{tabular} & $-0,07$ & 50,40 \\
\hline 13,55 & 9,90 & 3,91 & 1,42 & 0,25 & 49,50 & 46,40 & 38,50 & 20,46 & 58,41 & 107,74 & $-0,07$ & 51,30 \\
\hline 13,55 & 9,90 & 3,11 & 1,42 & 0,35 & 52,19 & 48,16 & 39,56 & 19,59 & 58,48 & 108,60 & $-0,04$ & 54,20 \\
\hline 13,59 & 9,94 & 4,92 & 1,31 & 0,52 & 54,35 & 50,17 & 45,40 & 19,82 & 58,34 & \begin{tabular}{|l|}
109,93 \\
\end{tabular} & 0,01 & 50,60 \\
\hline 13,64 & 9,99 & 5,14 & 1,20 & 0,60 & 55,59 & 52,15 & 38,92 & 20,70 & 58,06 & 109,93 & 0,01 & 48,90 \\
\hline 10,89 & 9,21 & 1,30 & 0,06 & 0,01 & 53,21 & 55,58 & 68,35 & 27,06 & 54,58 & 85,62 & $-0,14$ & 49,60 \\
\hline 10,97 & 9,29 & 3,44 & 0,07 & 0,02 & 57,12 & 64,56 & 67,53 & 30,65 & 55,90 & 86,03 & $-0,18$ & 48,30 \\
\hline 11,03 & 9,34 & 4,55 & 0,07 & 0,02 & 56,97 & 63,40 & 66,80 & 30,09 & 55,97 & 87,94 & $-0,04$ & 42,90 \\
\hline 11,08 & 9,39 & 5,57 & 0,91 & 0,02 & 62,33 & 62,81 & 66,18 & 25,58 & 54,18 & 90,09 & $-0,07$ & 41,60 \\
\hline 11,14 & 9,46 & 5,30 & 1,22 & 0,03 & 69,05 & 70,60 & 65,27 & 26,75 & 55,98 & 92,57 & $-0,02$ & 40,60 \\
\hline 11,24 & 9,55 & 6,61 & 1,93 & 0,06 & 72,30 & 75,43 & 60,44 & 29,67 & 54,97 & 93,28 & $\mathbf{0 , 0 1}$ & 34,10 \\
\hline 11,34 & 9,66 & 8,49 & 1,90 & 0,06 & 81,24 & 83,39 & 67,56 & 28,47 & 54,91 & 92,68 & 0,00 & 31,00 \\
\hline 11,45 & 9,76 & 10,80 & 1,92 & 0,07 & 83,38 & 82,95 & 62,03 & 28,21 & 54,22 & 92,34 & 0,03 & 30,10 \\
\hline 11,52 & 9,84 & 5,48 & 2,04 & 0,12 & 80,15 & 81,92 & 52,20 & 28,41 & 55,83 & 91,74 & 0,09 & 28,50 \\
\hline 11,46 & 9,77 & $-5,58$ & 1,88 & 0,11 & 68,04 & 68,20 & 59,07 & 20,50 & 59,67 & 91,68 & 0,13 & 36,30 \\
\hline 11,55 & 9,86 & 5,62 & 1,76 & 0,05 & 77,32 & 77,63 & 56,23 & 23,87 & 57,19 & 92,26 & 0,09 & 41,20 \\
\hline 11,57 & 9,89 & 2,73 & 1,77 & 0,05 & 85,01 & 84,31 & 52,94 & 25,24 & 55,71 & 92,60 & 0,13 & 43,70 \\
\hline 11,61 & 9,92 & 1,72 & 2,04 & 0,11 & 91,04 & 85,52 & 59,00 & 20,67 & 56,07 & 92,60 & 0,17 & 52,20 \\
\hline 11,62 & 9,93 & 0,56 & 2,10 & 0,12 & 93,62 & 88,01 & 58,92 & 20,92 & 55,49 & 90,82 & 0,11 & 54,70 \\
\hline 11,66 & 9,97 & 2,65 & 2,37 & 0,14 & 91,52 & 86,70 & 49,27 & 21,75 & 55,07 & 90,68 & 0,10 & 53,50 \\
\hline 11,71 & 10,02 & 4,72 & 2,42 & 0,15 & 92,02 & 88,95 & 52,43 & 24,26 & 54,05 & 90,98 & 0,10 & 52,20 \\
\hline 11,65 & 9,96 & 1,99 & 2,36 & 0,14 & 93,73 & 90,78 & 52,97 & 23,05 & 55,08 & 91,25 & 0,13 & 51,80 \\
\hline 11,67 & 9,98 & 2,88 & 2,27 & 0,15 & 95,11 & 92,92 & 62,24 & 23,03 & 55,87 & 91,07 & 0,16 & 50,90 \\
\hline 11,72 & 10,03 & 3,89 & 2,00 & 0,21 & 96,09 & 94,06 & 54,89 & 23,43 & 55,93 & 91,07 & 0,14 & 48,90 \\
\hline
\end{tabular}

Source: UN Open data, WB, IOM, Eurostat, the authors

The original data is organized in the form of a pooled panel data to sequence of Czechia, Hungary, Poland, and Slovakia. The sectorial, time invariant variables, Crise06 and Crise10, as well as the sectorial variables representing the individual countries of Czechia, Hungary, Poland, and Slovakia were added consequently. The descriptive statistics are presented in Table 2. 


\section{ENTREPRENEURSHIP AND SUSTAINABILITY ISSUES}

ISSN 2345-0282 (online) http://jssidoi.org/jesi/ 2020 Volume 8 Number 2 (December) http://doi.org/10.9770/jesi.2020.8.2(37)

Make your research more visible, join the Twitter account of ENTREPRENEURSHIP AND SUSTAINABILITY ISSUES: @Entrepr69728810

Table 2. Descriptive statistics of the original variables

\begin{tabular}{|c|c|c|c|c|c|c|c|c|c|c|c|c|}
\hline \multicolumn{13}{|c|}{ Descriptive statistics } \\
\hline PARAMETER & LN(GDPPC) & GDPPCG & \begin{tabular}{|c|} 
REMTIN \\
\% GDP \\
\end{tabular} & $\begin{array}{r}\text { REMTIOUT } \\
\% \text { GDP } \\
\end{array}$ & \begin{tabular}{|c|} 
Expoort \\
\% GDP \\
\end{tabular} & Import & $\begin{array}{l}\text { FDI } \\
\text { \%GDP } \\
\end{array}$ & $\begin{array}{l}\text { GCForm } \\
\% \text { GDP }\end{array}$ & $\begin{array}{c}\text { FCONSUMP } \\
\% \text { GDP } \\
\end{array}$ & $\begin{array}{l}\text { TRADE } \\
\% \text { GDP } \\
\end{array}$ & $\begin{array}{l}\text { POPUL } \\
\text { \% Growth }\end{array}$ & $\begin{array}{l}\text { DEBT } \\
\% \text { GDP } \\
\end{array}$ \\
\hline alid cases & 76 & 76 & 76 & 76 & 76 & 76 & 56 & 76 & 76 & 76 & 76 & 76 \\
\hline Mean & 9.732 & 3300 & 1.644 & 0.305 & 65.415 & 64.221 & 55.424 & 24.594 & 54.596 & 97,492 & -0.030 & 48.283 \\
\hline th. error of mean & 0.031 & 0.317 & 0.120 & 0.027 & 2.205 & 1.938 & 1.750 & 0.421 & 0.593 & 0.658 & 0.029 & 1.757 \\
\hline Variance & 0.072 & 7.657 & 1.088 & 0.054 & 369.613 & 285.391 & 171.578 & 13.497 & 26.690 & 32.942 & 0.063 & 234.542 \\
\hline Stdd. Deviation & 0.668 & 2.767 & 1.043 & 0.233 & 19.225 & 16.894 & 13.099 & 3.674 & 5.166 & 5.740 & 0.52 & 15.315 \\
\hline Variation Coefficient & 0.028 & 0.839 & 0.634 & 0.763 & 0.294 & 0.663 & 0.336 & 0.149 & 0.095 & 0.059 & 8.479 & 0.317 \\
\hline Skew & -0.463 & $-1,138$ & 0.472 & 0.595 & -0.273 & -0.268 & -0.290 & 0.191 & 0.305 & 0.298 & -0.107 & 0.430 \\
\hline Kurtosis & -0.567 & 3.415 & .0 .556 & -0.693 & -0.991 & -0.970 & .0 .515 & -0.974 & -0.702 & -0.522 & 4.094 & .0 .311 \\
\hline Minimum & 9.138 & .6 .555 & 0.061 & 0.013 & 27,229 & 30.845 & 27,801 & 18,445 & 46,061 & 85.617 & $-1,044$ & 17,000 \\
\hline Maximum & 10.240 & 10.800 & 3.828 & 0.894 & 96.090 & 94.065 & 81.554 & 32.072 & 66.332 & 1099,934 & 0.829 & 80,500 \\
\hline Range & 1.102 & 17.355 & 3.767 & 0.882 & 68.861 & 63.219 & 53.854 & 13.627 & 20.272 & 24.316 & 1.874 & 63.500 \\
\hline Sum & 739.62 & 250.80 & 124.96 & 23.20 & $4,971.55$ & $4,880,79$ & $3,103,75$ & $1,869.13$ & 4,199.27 & $7,409.38$ & .2 .26 & 3,66950 \\
\hline Sth percentile & 9.219 & $-1,619$ & 0.259 & 0.020 & 32.696 & 35.350 & 30.659 & 19.281 & 47.026 & 88.261 & -0.307 & 27,260 \\
\hline 10th percentile & 9.319 & 0.513 & 0.369 & 0.055 & 37,655 & 39.362 & 38.236 & 20.133 & 47.737 & 90,932 & -0.284 & 28,300 \\
\hline 25th percentile & 9.556 & 1.980 & 0.629 & 0.107 & 49.145 & 48.229 & 44.735 & 20.924 & 49.817 & 92.833 & -0.195 & 36.875 \\
\hline Median & 9.773 & 3.759 & 1.613 & 0.236 & 66.219 & 65.559 & 58.694 & 24.644 & 54.578 & 96,227 & .0 .032 & 47,600 \\
\hline 75th percentile & 9.946 & 4.981 & 2.084 & 0.509 & 81.623 & 78.546 & 65.232 & 27.107 & 58.268 & 102.951 & 0.107 & 54.775 \\
\hline goth percentile & 10.018 & 5.834 & 3.396 & 0.660 & 88.896 & 84.672 & 70.562 & 30.056 & 61.814 & 105.271 & 0.224 & 76.180 \\
\hline 95th percentile & 10.140 & 6.685 & 3.719 & 0.717 & 93.632 & 89.222 & 76.478 & 31.114 & 64.207 & 107.872 & 0.336 & 77.635 \\
\hline
\end{tabular}

To assess the mutual relation among the variables that were analyzed, their partial correlation coefficients have also been calculated, as presented in Table 3 . 


\section{ENTREPRENEURSHIP AND SUSTAINABILITY ISSUES}

ISSN 2345-0282 (online) http://jssidoi.org/jesi/ 2020 Volume 8 Number 2 (December) http://doi.org/10.9770/jesi.2020.8.2(37)

Make your research more visible, join the Twitter account of ENTREPRENEURSHIP AND SUSTAINABILITY ISSUES: @Entrepr69728810

Table 3. Coefficients of partial correlation, Pearson

\begin{tabular}{|c|c|c|c|c|c|c|c|c|c|c|c|c|}
\hline \multicolumn{13}{|c|}{ Pearson correlation coefficients } \\
\hline & $L N(G D P p C)$ & GDPpc G & REMITIN & REMIT OUT & oort & Import & FDI & GCForm & FCONSUMP & PTRADE & POPUL & DEBT \% GDP \\
\hline LN(GDPpc) & 1 & & & & & & & & & & & \\
\hline GDPpc G & $-0,157$ & 1 & & & & & & & & & & \\
\hline REMIT IN & 0,473 & 0,068 & 1 & & & & & & & & & \\
\hline REMIT OUT & 0,490 & $-0,255$ & $-0,001$ & 1 & & & & & & & & \\
\hline Export & 0,631 & $-0,108$ & 0,350 & 0,161 & 1 & & & & & & & \\
\hline Import & 0,529 & $-0,052$ & 0,273 & 0,079 & 0,984 & 1 & & & & & & \\
\hline FDI & 0,325 & $-0,287$ & $-0,021$ & 0,283 & 0,774 & 0,733 & 1 & & & & & \\
\hline GCForm & 0,024 & 0,327 & $-0,532$ & 0,256 & 0,089 & 0,159 & 0,175 & 1 & & & & \\
\hline FCONSUMP\% & $-0,590$ & 0,071 & 0,080 & $-0,624$ & $-0,594$ & $-0,542$ & $-0,662$ & $-0,615$ & 1 & & & \\
\hline TRADE & 0,218 & 0,025 & 0,444 & 0,210 & $-0,178$ & $-0,292$ & $-0,054$ & $-0,445$ & 0,061 & 1 & & \\
\hline POPUL & 0,532 & $-0,130$ & $-0,095$ & 0,317 & 0,186 & 0,151 & $-0,159$ & 0,224 & $-0,303$ & $-0,151$ & 1 & \\
\hline DEBT & 0,010 & $-0,246$ & 0,528 & $-0,013$ & 0,342 & 0,309 & 0,315 & $-0,583$ & 0,095 & 0,263 & $-0,449$ & 1 \\
\hline
\end{tabular}

Source: World Bank, the authors

Particular interest is focused on the values of correlation coefficients between the dependent variables $\mathrm{LN}(\mathrm{GDPpc})$ and the core studied explanatory variables of REMIN and REMOUT. Figure 1 presents the linear regressions between these variables under the pooled panel data scheme.
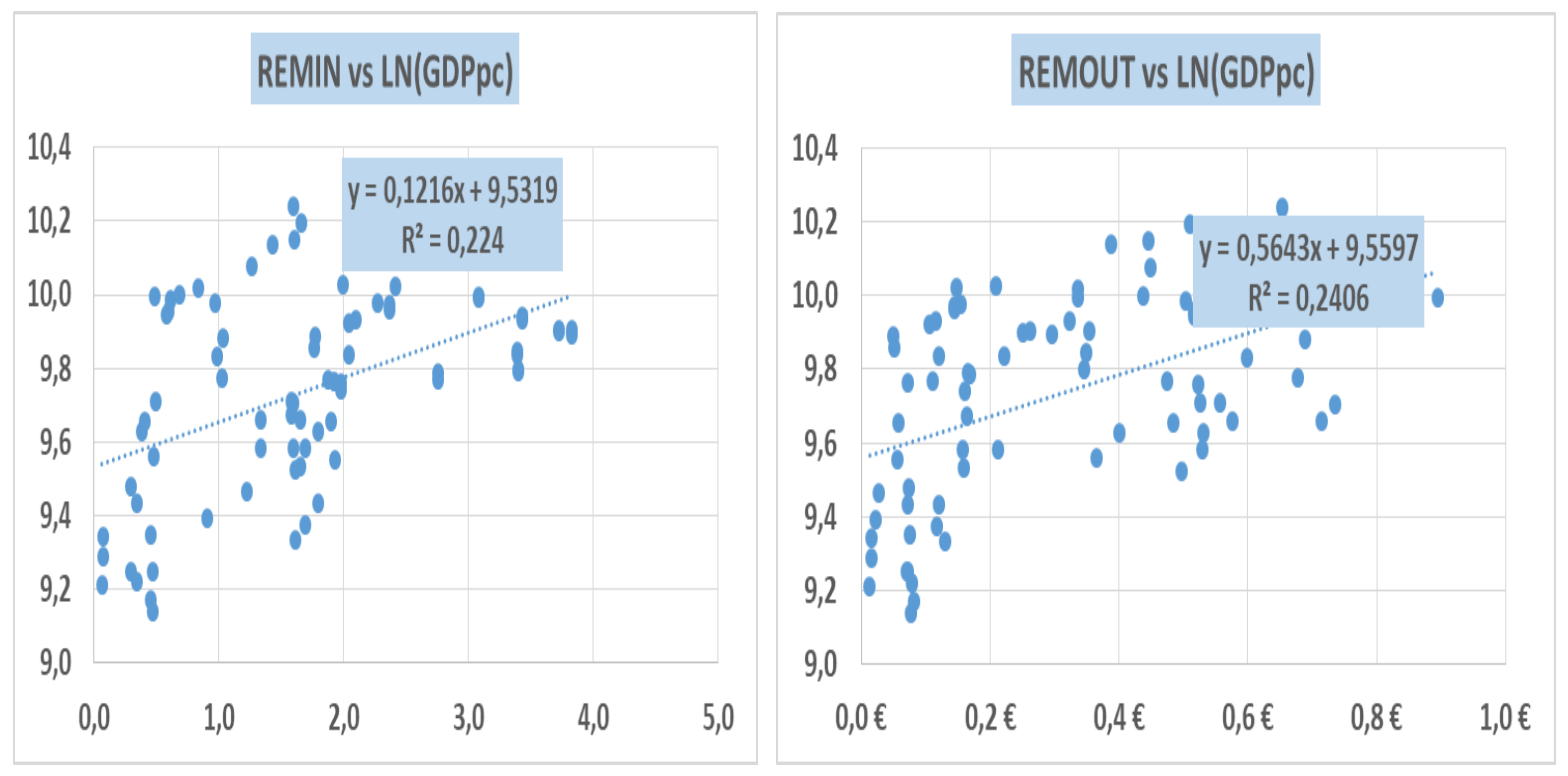

Fig. 1. Linear regression between LN(GDPpc) and REMIN, REMOUT

Source: World Bank, the authors 


\section{ENTREPRENEURSHIP AND SUSTAINABILITY ISSUES}

ISSN 2345-0282 (online) http://jssidoi.org/jesi/

2020 Volume 8 Number 2 (December)

http://doi.org/10.9770/jesi.2020.8.2(37)

Make your research more visible, join the Twitter account of ENTREPRENEURSHIP AND SUSTAINABILITY ISSUES: @Entrepr69728810

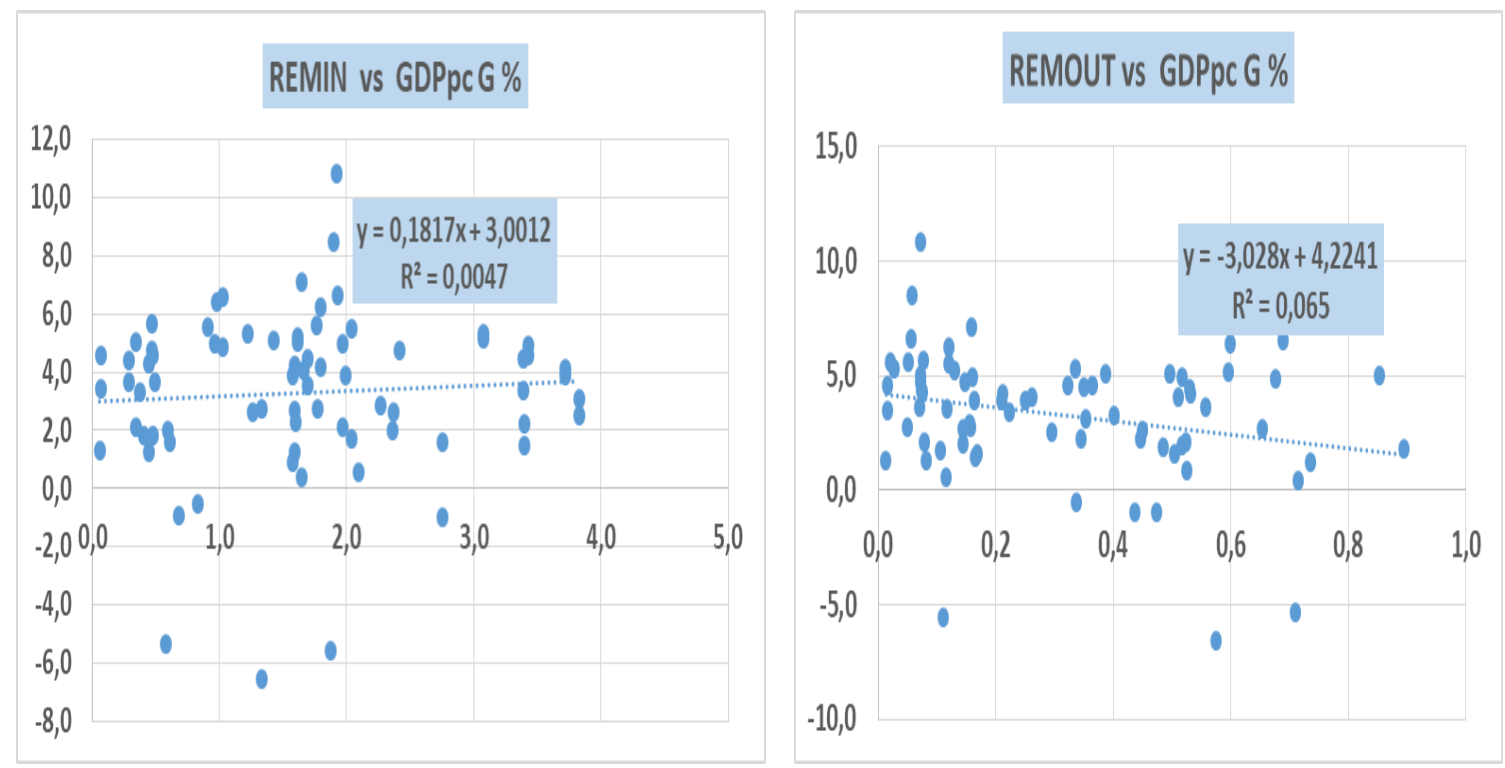

Fig. 2. Linear regression between $\mathrm{LN}(\mathrm{GDPpc}-\mathrm{G})$ and REMIN, REMOUT

Source: World Bank, author

As expected, the analysis of data in the pooled form, without respecting the sectoral time invariant factors, demonstrates relatively low correlation ties (see Figure 2). However, a significantly different situation is presented if the data is analyzed for individual countries, as demonstrated in Figure 3.
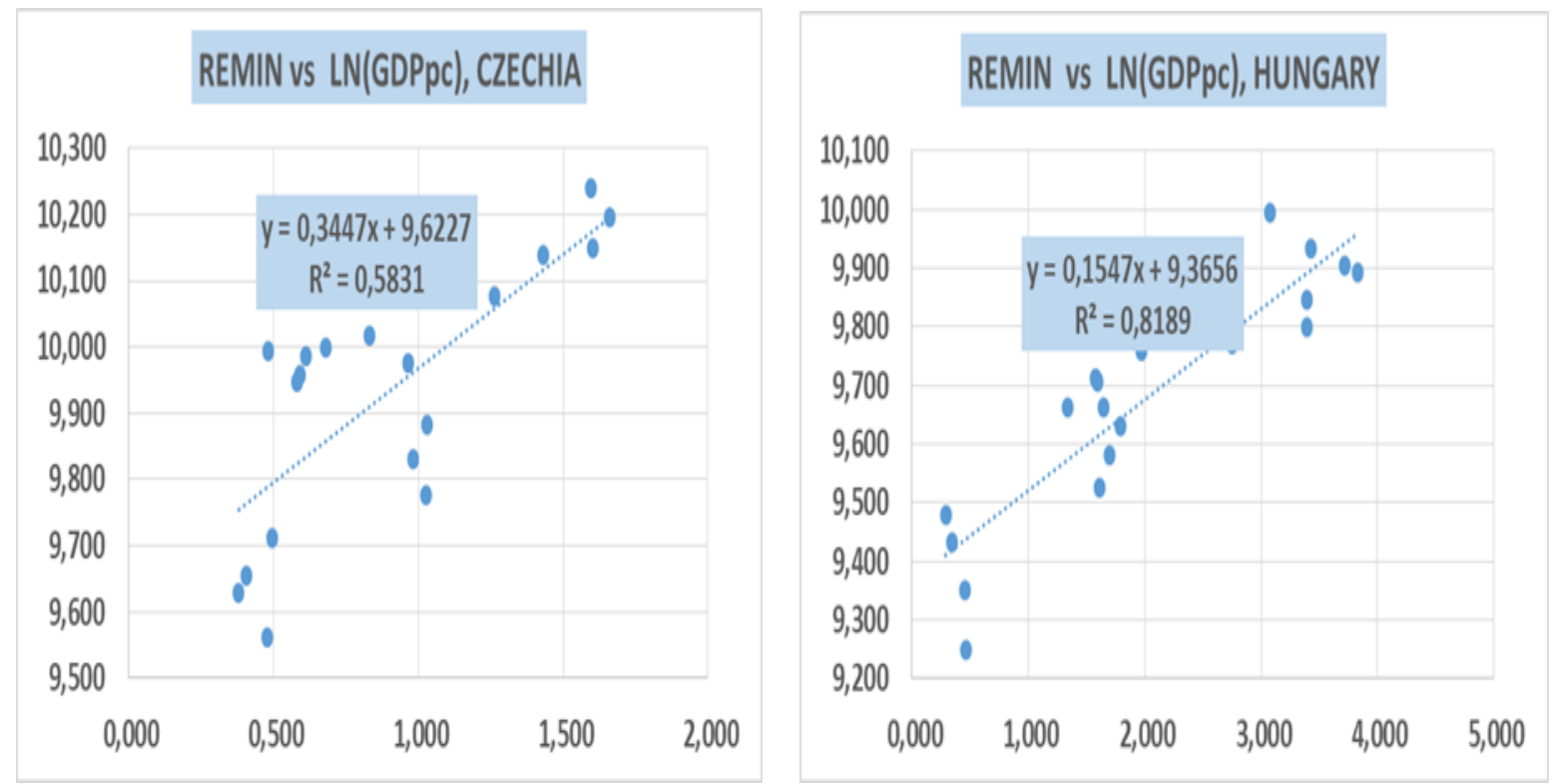
Make your research more visible, join the Twitter account of ENTREPRENEURSHIP AND SUSTAINABILITY ISSUES: @Entrepr69728810

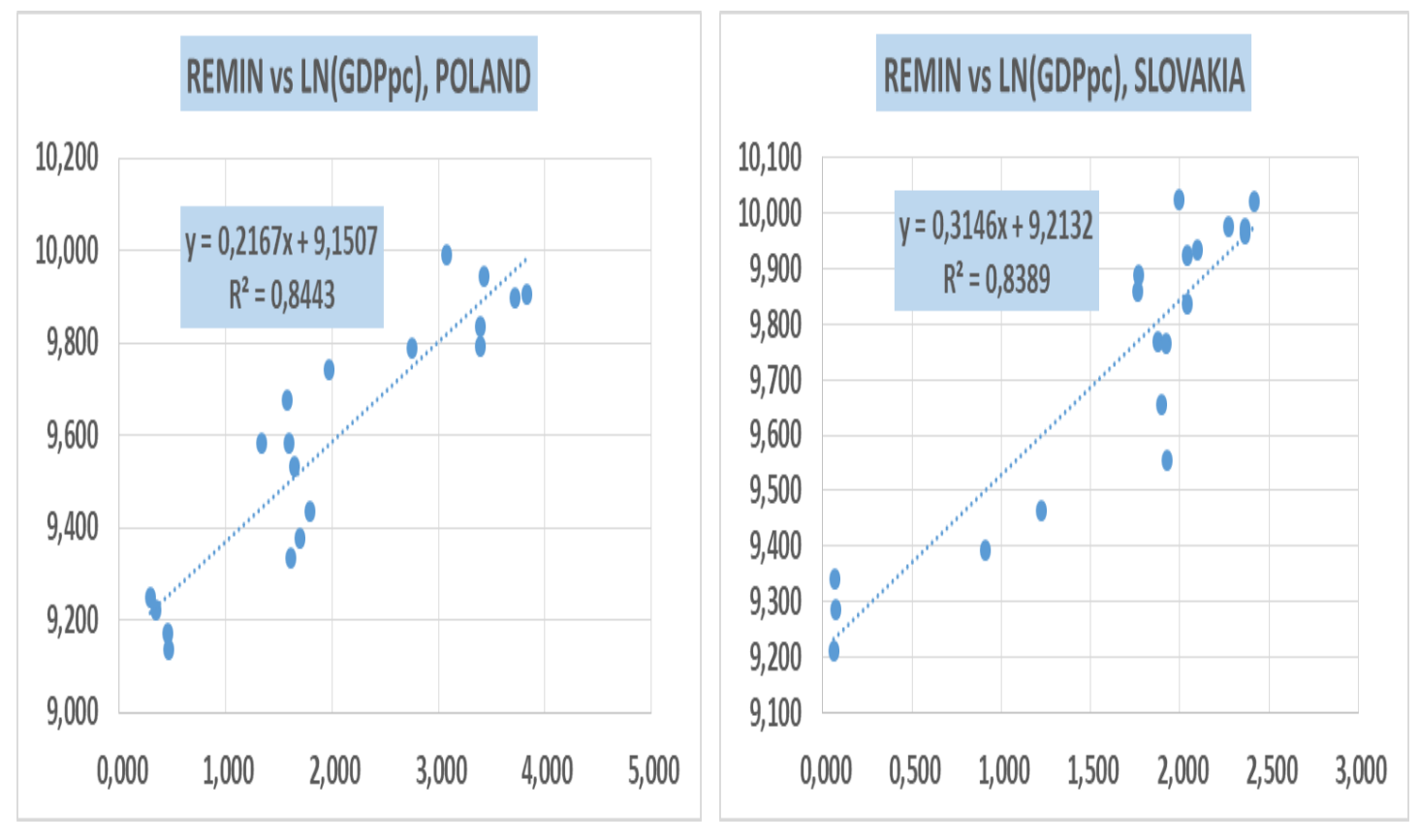

Figure 3. Linear regression between LN(GDPpc) and REMIN for individual countries

Source: World Bank, the authors

The last figures present the need to adopt the panel data approach, with sectoral variables reflecting the country specificities.

With reference to the published findings, specifically those of Aldrich (37), Aisbett (38), Kahn (39), Panizza (41), neither high nor statistically significant values of the correlation indicators do not confirm the causal relationship among the considered variables. They only reflect their correlation closeness and this should be respected in interpretation of the results of following statistical analysis.

\section{Remittances as a factor of economic growth in the V4 countries}

In line with the methodology of this paper, the main factors to further monitor the volume and growth of gross domestic product per capita are the following independent variables:

- The inflow of remittances into V4 countries

- The outflow of remittances from V4 countries

According the officially reported data presented in Table 4, more than USD 613 billion was redistributed worldwide in 2017, which confirms the significance of monitoring and analyzing the remittance flows.

The total EU transfers amounted to USD 147 billion in 2017, of which USD 77 billion were directed to nonmember countries, particularly to the low-income developing countries. 
ENTREPRENEURSHIP AND SUSTAINABILITY ISSUES

ISSN 2345-0282 (online) http://jssidoi.org/jesi/

2020 Volume 8 Number 2 (December)

http://doi.org/10.9770/jesi.2020.8.2(37)

Make your research more visible, join the Twitter account of ENTREPRENEURSHIP AND SUSTAINABILITY ISSUES: @Entrepr69728810

Table 4. Remittance flows between EU and non-EU countries

\begin{tabular}{|c|c|c|c|}
\hline \multicolumn{4}{|c|}{ Remittance flows between $E U$ and Non-EU countries } \\
\hline \multicolumn{4}{|c|}{ Volume of remittance flows 2017 , mil USD } \\
\hline & EU & NON EU & Spolu \\
\hline EU & 70290 & 77691 & 147981 \\
\hline NON EU & 53989 & 411494 & 465483 \\
\hline Total & 124279 & 489185 & 613464 \\
\hline \multicolumn{4}{|c|}{ Share of remittance flows, $2017, \%$} \\
\hline & EU & NON EU & Spolu \\
\hline EU & 11,46 & 12,66 & 24,12 \\
\hline NON EU & 8,80 & 67,08 & 75,88 \\
\hline Total & 20,26 & 79,74 & 100 \\
\hline
\end{tabular}

To clarify the current situation related to remittance flows and their expected positive impact on economic growth in selected EU countries, we present the statistical data on remittance inflows in the V4 countries for the 20002018 period, Figure 4a.

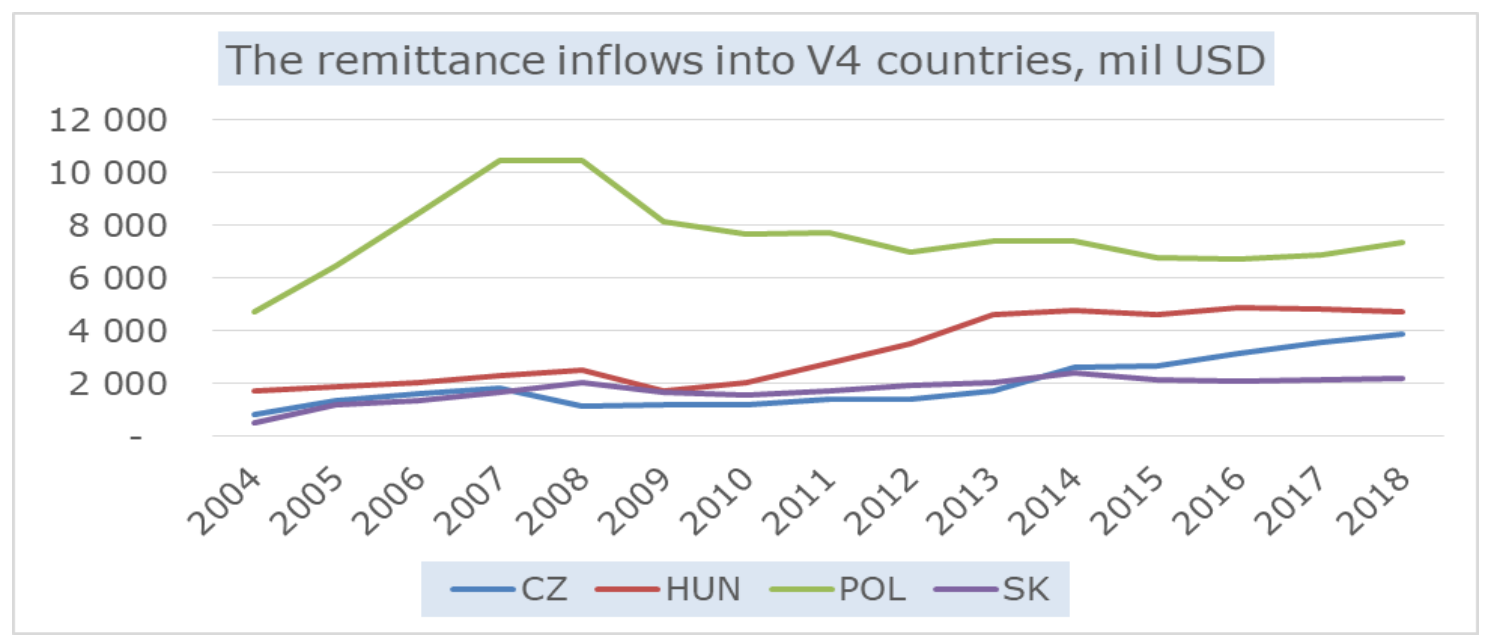

Fig. 4. Inflows of remittances into V4, mil. USD

Source: IOM, the authors

The highest share of remittances gained (as \% of GDP) among the V4 countries was Hungary (3\%), while the share of Slovakia's remittances reached 2.1\%. In Czechia and Poland, where labor markets have not been severely weakened over the studied period, the share of remittances was slightly lower with $1.6 \%$ and $1.3 \%$, respectively.

Concerning the final destination of these finances, the households in Slovakia received total transfers in 2018 of more than USD 2.21 billion, and since 2004, the total was over USD 26 billion. Of this amount, more than 87\% were transfers from EU countries, mainly the UK, Czechia, Germany, and Austria.

The V4 countries, as an organic part of the European Union's economic and social space, also created a wide scope for a foreign labor force that involves the subsequent financial compensation of foreign workers in the form of remittance outflows, as presented in Figure 4b. 


\section{ENTREPRENEURSHIP AND SUSTAINABILITY ISSUES}

ISSN 2345-0282 (online) http://jssidoi.org/jesi/

2020 Volume 8 Number 2 (December)

http://doi.org/10.9770/jesi.2020.8.2(37)

Make your research more visible, join the Twitter account of ENTREPRENEURSHIP AND SUSTAINABILITY ISSUES: @Entrepr69728810

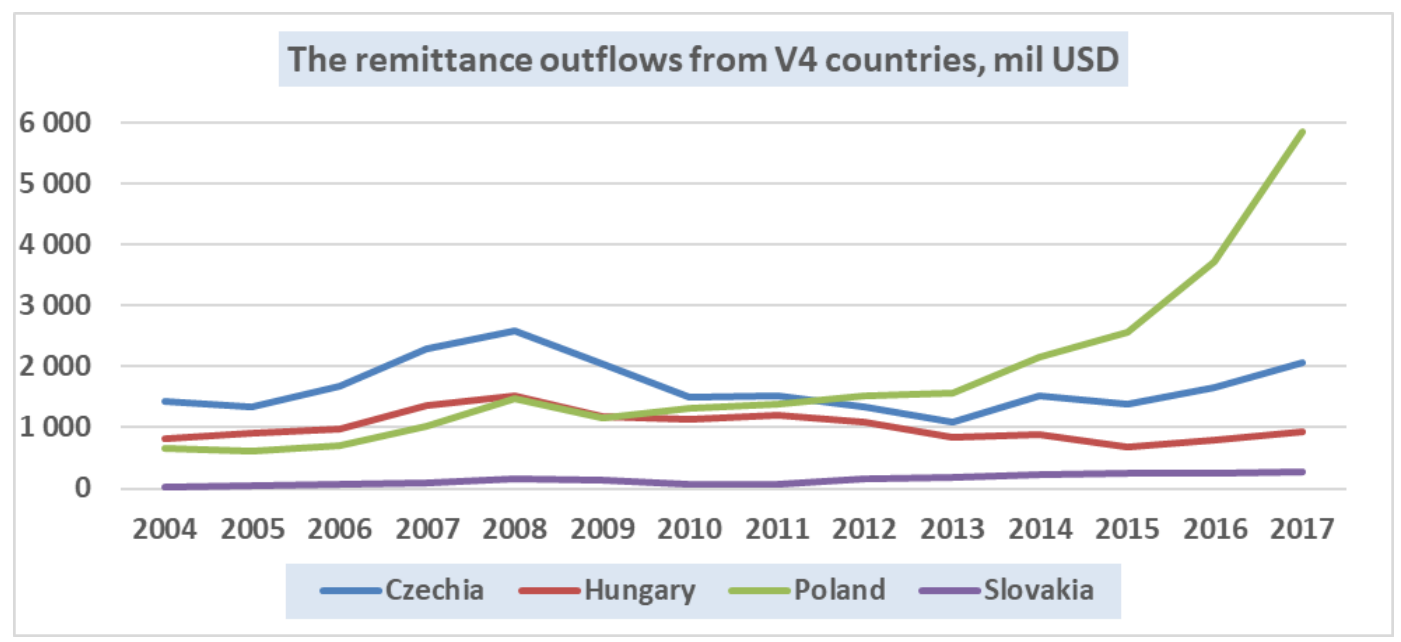

Fig. 4b. The remittance outflows from V4 countries, mil. USD Source: IOM, the authors

The volume of outflow remittances was significantly lower than the volume of remittances received. In 2018, the volume of remittance paid in Czechia was USD 2.758 billion, USD 1.011 billion in Hungary, USD 7.094 billion in Poland, and USD 0.385 billion in Slovakia. In these countries, the share of the disbursement paid was $1.13 \%$ in Czechia, $0.656 \%$ in Hungary, $1.211 \%$ in Poland, and only $0.361 \%$ in Slovakia. The total volume of remittances paid in Slovakia for the entire period of 2000-2018 amounted to USD 2.3 billion.

The growth of the GDP per capita and the volume of remittance per capita is presented in Figure 5. While the development of GDPpc in the V4 countries follows a similar mode in economic growth with the leading position of Czechia and Slovakia, the inflows of remittances in these countries indicates a different pattern with leading positions for Hungary and Slovakia.

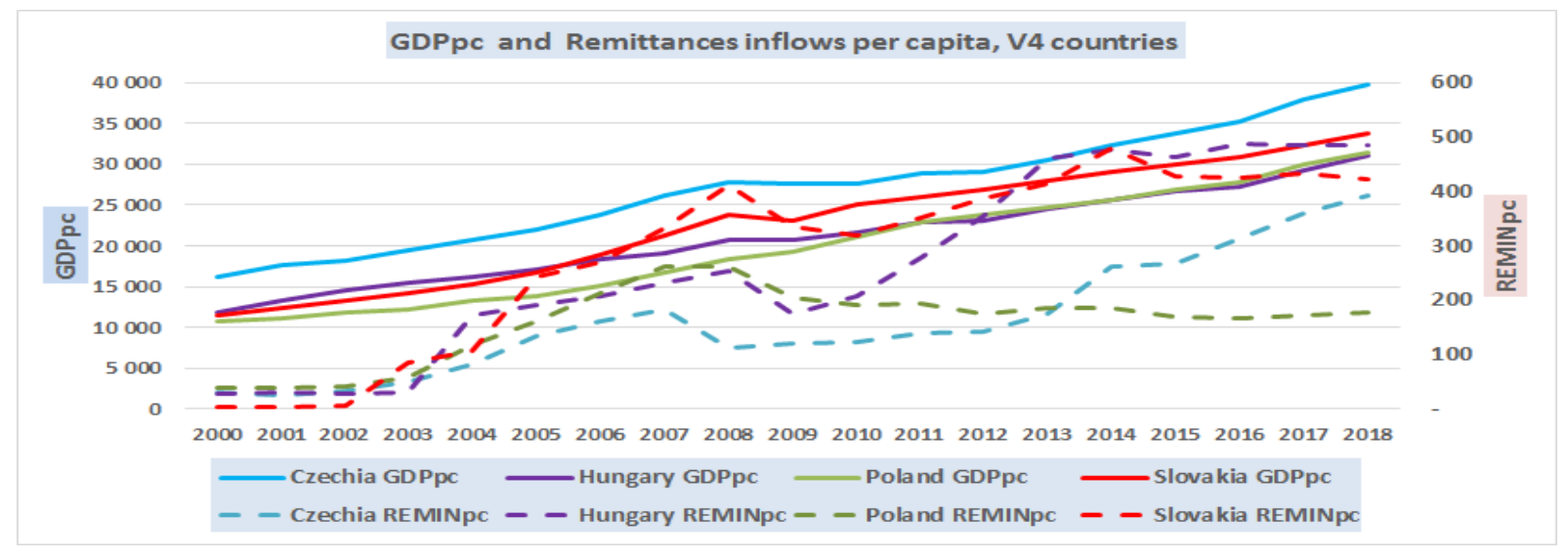

Fig. 5. Dynamics of GDPpc and the remittances received per capita Source: IOM, the authors 
ENTREPRENEURSHIP AND SUSTAINABILITY ISSUES

ISSN 2345-0282 (online) http://jssidoi.org/jesi/ 2020 Volume 8 Number 2 (December)

http://doi.org/10.9770/jesi.2020.8.2(37)

Make your research more visible, join the Twitter account of ENTREPRENEURSHIP AND SUSTAINABILITY ISSUES: @Entrepr69728810

\section{Solution of econometric models (2) and (3)}

To confirm the initially formulated hypotheses $\mathrm{H} 1$ and $\mathrm{H} 2$, the models (2) and (3) and their solutions are presented. The dependent variables LN(GDPpc) and GDPpc-G are expressed through the set of explanatory variables defined earlier. The solutions of these models are presented under three scenarios and two forms.

The first scenario offers the pooled linear regression for estimating dependent variable LN(GDPpc). The explanatory variables are presented in Table 1.

Under the second scenario the dependent variable is estimated through expanded list of explanatory variables, where the time invariant variables representing individual countries are taken into account.

The third scenario considers also the expected external impact of economic crisis in 2009 and 2010 toward all studied countries.

All solution are presented in two form A and B. The form A contains all explanatory variables, while the form B contains only a list of statistically significant variables with $\mathrm{p}<0.05$ (see Table 5).

Table 5. Model (2)

\begin{tabular}{|c|c|c|c|c|c|c|c|c|c|c|c|c|}
\hline \multicolumn{5}{|l|}{ Table 5} & \multicolumn{4}{|c|}{ Solutions to Model 2} & & & & \\
\hline \multicolumn{13}{|c|}{$\mathrm{Y}=\mathrm{LN}(\mathrm{GDPpc})$} \\
\hline & \multicolumn{4}{|c|}{ Pooled regresslon } & \multicolumn{4}{|c|}{ Expanded model - Countrles } & \multicolumn{4}{|c|}{ Expended model - Crisls } \\
\hline & \multicolumn{2}{|c|}{ A } & \multicolumn{2}{|l|}{ B } & \multicolumn{2}{|l|}{ A } & \multicolumn{2}{|l|}{ B } & \multicolumn{2}{|c|}{ A } & \multicolumn{2}{|c|}{ B } \\
\hline & Coefficlent & $\mathbf{P}$ & Coefficlent & $\mathbf{P}$ & Coefficlent & $\mathbf{P}$ & Coefficlent & $\mathbf{P}$ & Coeff. & $\mathbf{P}$ & Coeff. & $\mathbf{P}$ \\
\hline Constant & 9,163 & 0,000 & 8,235 & 0,000 & 9,273 & 0,000 & 9,053 & 0,000 & 4,602 & 0,012 & 8,620 & 0,000 \\
\hline REMIN & 0,013 & 0,601 & & & 0,089 & 0,005 & 0,086 & 0,000 & 0,147 & 0,000 & 0,125 & 0,000 \\
\hline REMOUT & 0,021 & 0,827 & & & 0,023 & 0,825 & & & 0,097 & 0,278 & & \\
\hline & & & & & & & & & & & & \\
\hline EXPORT & 0,022 & 0,262 & 0,025 & 0,000 & $-0,024$ & 0,272 & & & 0,021 & 0,295 & & \\
\hline IMPORT & $-0,016$ & 0,437 & $-0,018$ & 0,004 & 0,037 & 0,111 & 0,016 & 0,000 & $-0,001$ & 0,942 & 0,020 & 0,000 \\
\hline FDI & $-0,004$ & 0,046 & $-0,004$ & 0,011 & $-0,001$ & 0,635 & & & $-0,004$ & 0,009 & $-0,003$ & 0,025 \\
\hline GCFORM & $-0,009$ & 0,652 & & & $-0,039$ & 0,105 & $-0,011$ & 0,006 & 0,021 & 0,383 & & \\
\hline FCONSUM & $-0,007$ & 0,729 & & & $-0,035$ & 0,194 & & & 0,037 & 0,181 & & \\
\hline TRADE & 0,011 & 0,015 & 0,013 & 0,000 & 0,001 & 0,792 & & & 0,001 & 0,751 & & \\
\hline POPUL & 0,334 & 0,005 & 0,454 & 0,000 & 0,295 & 0,009 & 0,375 & 0,000 & 0,221 & 0,025 & 0,275 & 0,000 \\
\hline DEBT & $-0,003$ & 0,119 & & & 0,000 & 0,899 & & & 0,000 & 0,943 & & \\
\hline CZECHIA & & & & & 2,481 & 0,000 & & & 1,539 & 0,000 & & \\
\hline HUNGARY & & & & & 2,102 & 0,000 & $-0,384$ & 0,000 & 0,998 & 0,026 & $-0,464$ & 0,000 \\
\hline POLAND & & & & & 2,534 & 0,000 & & & 1,237 & 0,023 & & \\
\hline SLOVAKIA & & & & & 2,155 & 0,000 & $-0,476$ & 0,000 & 0,829 & 0,071 & $-0,580$ & 0,000 \\
\hline Crlsls 09 & & & & & & & & & 0,212 & 0,000 & 0,192 & 0,000 \\
\hline Crisls 10 & & & & & & & & & 0,171 & 0,000 & 0,147 & 0,000 \\
\hline & & & & & & & & & & & & \\
\hline$R^{\wedge} \mathbf{2}$ & 0,838 & & 0,827 & & 0,899 & & 0,886 & & 0,936 & & 0,926 & \\
\hline
\end{tabular}

Source: IOM, the authors

Concerning the impact of remittance inflows, the variable REMIN is statistically significant according several versions of model (2). The highest level of reliability in explaining variability of dependent variable LN(GDPpc) is presented by Expanded model with time invariant variables representing individual countries and crises. The respective index of determination has a value of $\mathrm{R} 2=0.936$. The robustness of the model is presented by empiric and estimated time series data of LN(GDPpc), according the last presented model, Figure 6. 


\section{ENTREPRENEURSHIP AND SUSTAINABILITY ISSUES}

ISSN 2345-0282 (online) http://jssidoi.org/jesi/ 2020 Volume 8 Number 2 (December) http://doi.org/10.9770/jesi.2020.8.2(37)

Make your research more visible, join the Twitter account of ENTREPRENEURSHIP AND SUSTAINABILITY ISSUES: @Entrepr69728810

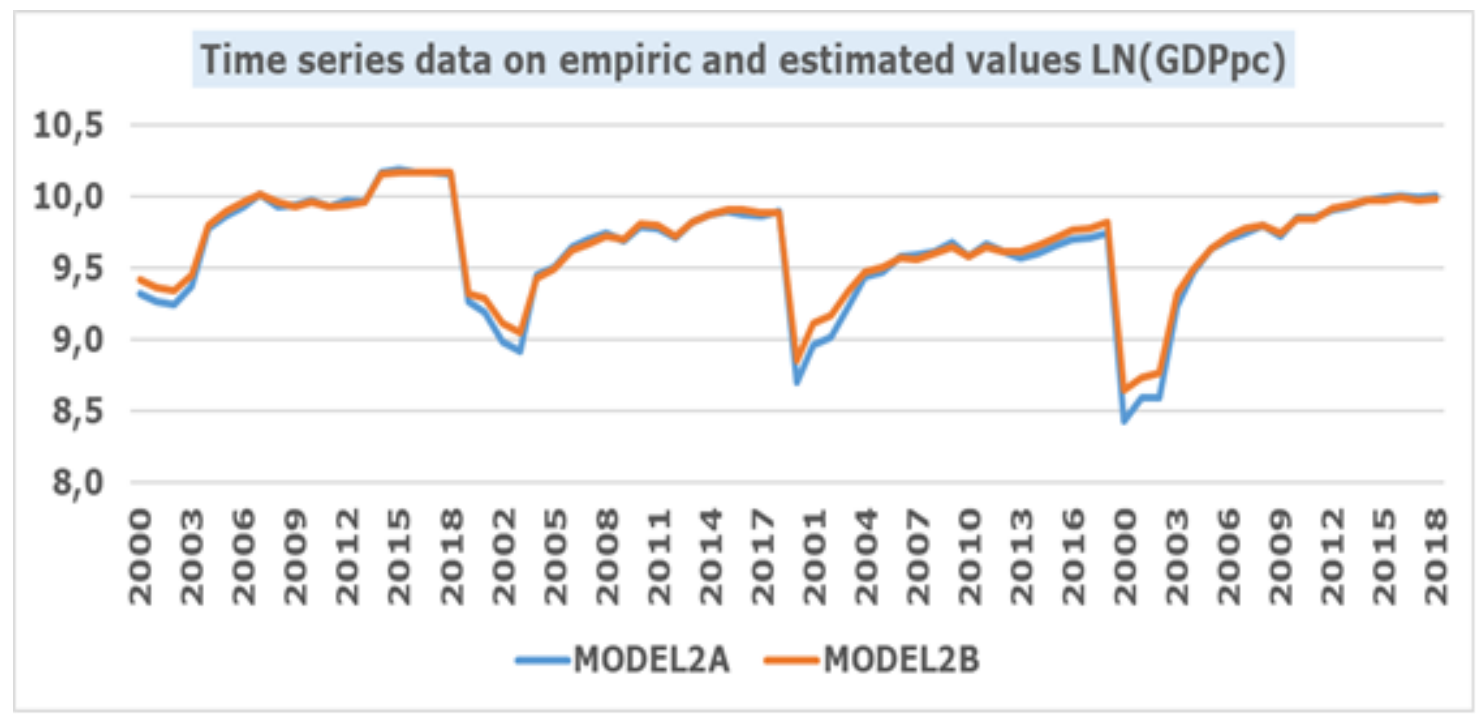

Fig. 6. The empiric and estimated values of LN(GDPpc)

Source: the authors

The time-invariant sectoral and country related variables for Hungary $=-0.3711$ and Slovakia $=-0.4356$ indicate a fairly strong effect on the nationally specific factors to transfer the remittance inflows into economic growth. To identify them, the additional variability analysis of the values LN(GDPpc) would be required by introducing the relevant "hedonic variables."

Table 6. Model (3)

\begin{tabular}{|c|c|c|c|c|c|c|c|c|c|c|c|c|}
\hline Table 6 & \multicolumn{11}{|c|}{ Solutions to Model 3} & \\
\hline & \multicolumn{11}{|c|}{$\mathbf{Y}=\mathbf{G D P p c}-\mathbf{G}$} & \\
\hline & \multicolumn{4}{|c|}{ Pooled regression } & \multicolumn{4}{|c|}{ Expanded model - Countries } & \multicolumn{4}{|c|}{ Expanded model - Cri\$is } \\
\hline & \multicolumn{2}{|l|}{ A } & \multicolumn{2}{|l|}{ B } & \multicolumn{2}{|c|}{ A } & \multicolumn{2}{|c|}{ B } & \multicolumn{2}{|c|}{ A } & \multicolumn{2}{|c|}{$\mathbf{B}$} \\
\hline & Coefficient & $\mathbf{P}$ & Coefficient & $\mathbf{P}$ & Coefficient & $\mathbf{P}$ & Coefficient & $\mathbf{P}$ & Coeff. & $\mathbf{P}$ & Coeff. & $\mathbf{P}$ \\
\hline Constant & $-97,485$ & 0,010 & $-42,340$ & 0,000 & 30,837 & 0,476 & $-42,340$ & 0,000 & 96,618 & 0,028 & $-21,905$ & 0,001 \\
\hline REMIN & 0,685 & 0,224 & 2,113 & 0,000 & $-0,536$ & 0,479 & 2,113 & 0,000 & $-1,373$ & 0,048 & & \\
\hline REMOUT & 0,574 & 0,787 & & & $-3,866$ & 0,148 & & & $-5,938$ & 0,009 & & \\
\hline EXPORT & 1,015 & 0,025 & & & 0,253 & 0,633 & & & $-0,296$ & 0,542 & & \\
\hline IMPORT & $-0,982$ & 0,034 & & & $-0,036$ & 0,949 & & & 0,415 & 0,406 & & \\
\hline FDI & $-0,103$ & 0,013 & & & $-0,083$ & 0,051 & & & $-0,026$ & 0,493 & & \\
\hline GCFORM & 1,824 & 0,000 & 0,967 & 0,000 & 0,485 & 0,415 & 0,967 & 0,000 & $-0,460$ & 0,425 & 0,537 & 0,000 \\
\hline FCONSUM & 0,997 & 0,022 & 0,331 & 0,000 & $-0,621$ & 0,357 & 0,331 & 0,000 & $-1,556$ & 0,022 & & \\
\hline \begin{tabular}{|l} 
TRADE \\
\end{tabular} & 0,037 & 0,707 & & & $-0,088$ & 0,446 & & & $-0,074$ & 0,423 & 0,184 & 0,000 \\
\hline POPUL & $-8,789$ & 0,001 & & & $-6,081$ & 0,029 & & & $-1,954$ & 0,400 & & \\
\hline DEBT & $-0,024$ & 0,573 & & & $-0,261$ & 0,008 & & & $-0,316$ & 0,000 & $-0,083$ & 0,000 \\
\hline CZECHIA & & & & & $-0,414$ & 0,965 & & & 12,094 & 0,184 & $-5,378$ & 0,000 \\
\hline HUNGARY & & & & & 9,807 & 0,367 & & & 27,426 & 0,012 & & \\
\hline POLAND & & & & & 18,124 & 0,182 & & & 35,649 & 0,008 & & \\
\hline SLOVAKIA & & & & & 3,320 & 0,750 & & & 21,449 & 0,054 & & \\
\hline Crisis 09 & & & & & & & & & $-5,385$ & 0,000 & $-5,502$ & 0,000 \\
\hline Crisis 10 & & & & & & & & & 0,337 & 0,728 & & \\
\hline & & & 0.5309 & & & & 0.5309 & & 0.8634 & & 07267 & \\
\hline
\end{tabular}

Source: author 
Make your research more visible, join the Twitter account of ENTREPRENEURSHIP AND SUSTAINABILITY ISSUES: @Entrepr69728810

All solutions to Model 3 (see Table 6) demonstrate slightly lower degrees of coherence among the empiric and estimated data. Total variability in GDPpc-G values is covered by the identified explanatory variables to maximum at $86 \%$ (respectively $77 \%$ ). The empiric and estimated time series of GDPpc-G are presented on Figure 7.

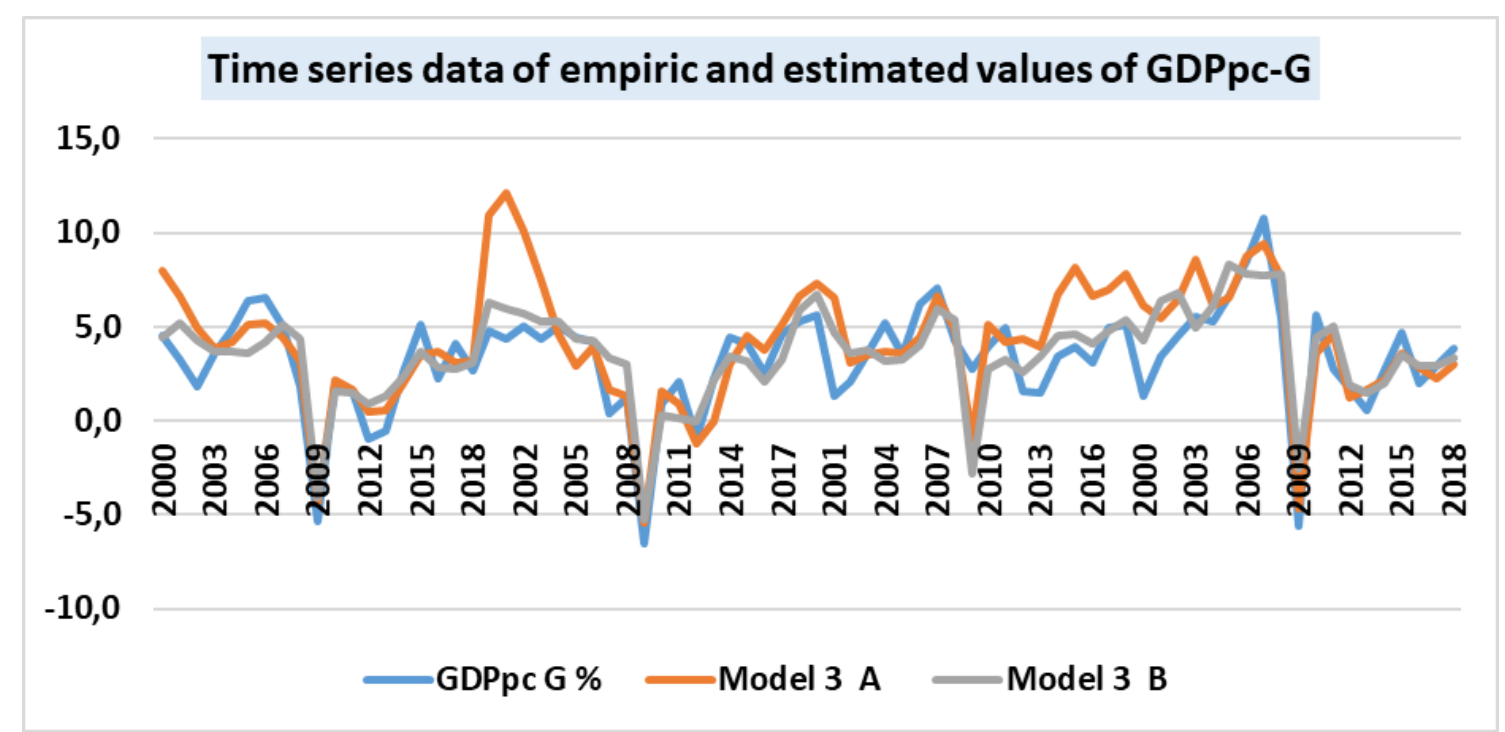

Fig. 7. Time series of empiric and estimated values for Models $2 \mathrm{~A}$ and 2B

Source: the authors

Based on the results of all presented models, the statistically significant impact of the remittance inflows on GDPpc volume and GDPpc-G growth of hosting countries was identified by both econometric models. Results obtained by these econometric models could be accepted as a confirmation of the working hypotheses, H1 and $\mathrm{H} 2$. In the economic interpretation, this finding means that remittance inflows in the Visegrad group countries (V4) during the period 2000-2018 had positive impact on economic growth measured by volume of GDPpc as well as on annual growth of GDPpc.

\section{Granger causuality approach}

The last step in evaluating the importance and validity of the impact of remittance inflows is the Granger causality test between variables LN(GDPpc) and REMIN and $\mathrm{LN}(\mathrm{GDPpc}-\mathrm{G})$ and REMIN. The results are presented below in Table 7: 
ENTREPRENEURSHIP AND SUSTAINABILITY ISSUES

ISSN 2345-0282 (online) http://jssidoi.org/jesi/

2020 Volume 8 Number 2 (December)

http://doi.org/10.9770/jesi.2020.8.2(37)

Make your research more visible, join the Twitter account of ENTREPRENEURSHIP AND SUSTAINABILITY ISSUES: @Entrepr69728810

Table 7. Results of Granger Causality Testing for Model 2

\begin{tabular}{|l|lll||}
\hline Pairwise Granger Causality Tests & & & \\
Date: 06/30/20 Time: 23:15 & & & \\
Sample: 176 & Obs & & \\
Lags: 2 & & & \\
\hline \hline Null Hypothesis: & 74 & $\mathbf{1 . 2 9 6 8 0}$ & $\mathbf{0 . 2 8 0 0}$ \\
\hline REM-IN does not Granger Cause LN(GDPpc) & & $\mathbf{4 . 0 5 0 7 2}$ & $\mathbf{0 . 0 2 1 7}$ \\
LN(GDPpc) does not Granger Cause REM-IN & & \\
\hline
\end{tabular}

Source: Eviews, author

According the results above, we cannot reject the hypothesis that REM-IN does not Granger cause LN(GDPpc); however, we reject the hypothesis that LN(GDPpc) does not Granger cause REM-IN. This indicates that the Granger causality runs in the direction from LN(GDPpc) to REM-IN (see Table 8).

Table 8. Results of Granger Causality Testing for Model 3

\begin{tabular}{|c|c|c|c|}
\hline $\begin{array}{l}\text { Pairwise Granger Causality Tests } \\
\text { Date: } 06 / 30 / 20 \text { Time: } 23: 31 \\
\text { Sample: } 176 \\
\text { Lags: } 2\end{array}$ & & & \\
\hline Null Hypothesis: & Obs & F-Statistic & Prob. \\
\hline REM-IN does not Granger Cause LN(GDPpc-G) & 74 & 1.02770 & 0.3632 \\
\hline LN(GDPpc-G) does not Granger Cause REM-IN & & 0.83185 & 0.4396 \\
\hline
\end{tabular}

Source: the authors

In the case of Model 3, we cannot reject neither of the two hypotheses.

These findings are in line with the previous conclusions about the impact of remittance inflows obtained by econometric models (2) and (3).

All the results of the above presented econometric analysis and the Granger causality tests offer qualified information about the ties among the studied variables. However, the presented results have only partially confirmed the positive impact of remittance inflows on economic growth in the studied countries. Despite the high value of the obtained information, the final interpretation of the results, namely their transformation into terms of causality, should be considered in the context of all the relevant economic and social dimensions. 
ENTREPRENEURSHIP AND SUSTAINABILITY ISSUES

ISSN 2345-0282 (online) http://jssidoi.org/jesi/

2020 Volume 8 Number 2 (December)

http://doi.org/10.9770/jesi.2020.8.2(37)

Make your research more visible, join the Twitter account of ENTREPRENEURSHIP AND SUSTAINABILITY ISSUES: @Entrepr69728810

\section{Conclusions}

The worldwide globalization of economies, their technological openness, and their interconnection also amplifies the national labor markets and consequently, the migration of workers from less developed countries into labor markets that offer higher compensations. These financial means or remittances are private incomes of individual workers. However, because of their high volumes, these means are considered as a possible source of economic growth of national economies of the mother countries. For this reason, remittance flows between the hosting and the mother countries of foreign workers has been a frequently discussed topic in professional literature.

The main goal of our discussion was to answer the research questions that were formulated through the two working hypotheses. As a methodological tool, we adopted the panel data analysis supported by econometric model techniques and Granger causality testing.

On the basis of the statistical information obtained, formulating the following positions on the working hypotheses is possible:

\section{Hypothesis 1:}

A statistically significant impact of remittances received on the volume of LN(GDPpc) has been confirmed based on Models 2A and 2B.

\section{Hypothesis 2:}

A statistically significant impact of the remittances received on the growth of GDPpc-C has not been confirmed based on Models 3A and 3B.

We consider that all the above findings should be interpreted as results based on the correlation and regression relationships, which do not provide sufficient arguments to confirm the generally valid positive causal relationship between the remittance received and the dynamics of the GDP in case of the four Visegrad group countries.

\section{References}

Adams, S., Mensah, Klobodub, E., K. 2016. Remittances, regime durability and economic growth in Sub-Saharan Africa (SSA). Economic Analysis and Policy, 50, 1-8. https://doi.org/10.1016/j.eap.2016.01.002. ISS 0313-5926

Aldrich, J. 1995. Correlation and Spurious Regression in Pearson and Yule, Statistical Science, 10(4), 364-376. ISSN: 0883-4237 (print), 2168-8745 (electronic)

Alvarez, S., P., et al. 2015. Remittances: How reliable are the data?. Migration Policy Practice https://publications.iom.int/system/files/pdf/mpp_issue_21.pdf, 


\section{ENTREPRENEURSHIP AND SUSTAINABILITY ISSUES}

ISSN 2345-0282 (online) http://jssidoi.org/jesi/

2020 Volume 8 Number 2 (December)

http://doi.org/10.9770/jesi.2020.8.2(37)

Make your research more visible, join the Twitter account of ENTREPRENEURSHIP AND SUSTAINABILITY ISSUES: @Entrepr69728810

Azam, M., Haseeb, M., Samsudin, S. 2016. The Impact of Foreign Remittances on Poverty Alleviation: Global Evidence, Economics and Sociology, 9(1), 264-281. https://doi.org/10.14254/2071-789X.2016/9-1/18 ISSN 2071-789X

Barajas, A., at all. 2009. Do Remittances Promote Economic Growth? IMF, July 2009.

https://books.google.sk/books?hl=sk\&lr=\&id=JQSXIKd1ZDUC\&oi=fnd\&pg=PA3\&dq=Do+Remittances+Promote+Economic+Growth\%3 F+IMF,\&ots=vrxUhGf0_Y\&sig=AIAVZxLwk10FI2SR25vJFy2WZo4\&redir_esc=y\#v=onepage\&q=Do\%20Remittances $\% 20$ Promote $\% 20$ Economic\%20Growth\%3F\%20IMF\%2C\&f=false

Berdiev, A., N. et all. 2013. Remittances and corruption, Economics Letters journal, 118(1), 182-185. ISSN 0165-1765.

Berwick, M. 2017. When Is Correlation Causation? Journal of National Cancer Institute, 109(8), djx087, https://doi.org/10.1093/jnci/djx087 ISSN 0027-8874, EISSN 1460-2105.

Bleske-Rechek, K. M., Heidke, L. 2015. Causal Inference from Descriptions of Experimental and Non-Experimental Research: Public Understanding of Correlation-Versus-Causation, The Journal of General Psychology, 142(1), 48-70. ISSN: 0022-1309 Online ISSN: 19400888

Castelli, F. 2018. Drivers of migration: why do people move?, Journal of Travel Medicine, 25(1) tay040, https://doi.org/10.1093/jtm/tay040

Chami, R. 2018. Is There a Remittance Trap?, Finance and Development, IMF.

Cismas, M., et all. 2019. The impact of remittances on the receiving country: some evidence from Romania in European context, Ekonomska Istraživanja / Economic Research, 2019 https://doi.org/10.1080/1331677X.2019.1629328 Print ISSN: 1331-677X Online ISSN: 1848-9664

Clemens, M., McKenzie, D. 2018. Why Don't Remittances Appear to Affect Growth?,The Economic Journal, 128(612), F179-F209, https://doi.org/10.1111/ecoj.12463 ISSN:1468-0297

Comes, C-A., Bunduchi, E., Vasile, V., Stefan, D. 2018. The Impact of Foreign Direct Investments and Remittances on Economic Growth: A Case Study in Central and Eastern Europe https://www.mdpi.com/2071-1050/10/1/238/pdf ISSN 2071-1050

Consumer Financial Protection Bureau.2020, http://www.consumerfinance.gov/

Coulibaly, D. 2015. Remittances and financial development in Sub-Saharan African countries: A system approach, Economic Modelling, 249-258. https://doi.org/10.1016/j.econmod.2014.12.005 ISSN: 0264-9993

Demirguc-Kunt, A., Ozden, C. 2019. Migration Trends in Europe and Central Asia, https://blogs.worldbank.org/peoplemove/migrationtrends-and-policies-europe-and-central-asia

Filipek, K., Polkowska, D. 2019. The Latent Precariousness of Migrant Workers: a Study of Ukrainians Legally Employed in Poland. Migration \& Integration 21, 205-220 (2020). https://doi.org/10.1007/s12134-019-00708-6

Guterres, A. 2018. Towards a new global compact migration, UN. https://www.un.org/sg/en/content/sg/articles/2018-01-11/towardsnewglobal-compact-migration

Hendrick, M., Bartram, D. 2019. Bringing Happiness Into the Study of Migration and Its Consequences: What, Why, and How?, Journal of Immigrant \& Refugee Studies, 17, ISSN: 1556-2948 (Print) 1556-2956 (Online) Journal homepage: https://www.tandfonline.com/loi/wimm2

Hoerder, D. 2017. Introduction to the Special Issue on Migration in Slavic, Tsarist Russian and Soviet History, Journal of Migration History, https://doi.org/10.1163/23519924-00302001

https://www.imf.org/external/pubs/ft/fandd/2018/09/pdf/is-there-a-remittance-trap-chami.pdf 


\section{ENTREPRENEURSHIP AND SUSTAINABILITY ISSUES}

ISSN 2345-0282 (online) http://jssidoi.org/jesi/

2020 Volume 8 Number 2 (December)

http://doi.org/10.9770/jesi.2020.8.2(37)

Make your research more visible, join the Twitter account of ENTREPRENEURSHIP AND SUSTAINABILITY ISSUES: @Entrepr69728810

In: Drivers for Progress in the Global Society: The 3rd European Interdisciplinary Forum 2015, Vilnius June 18-19 2015. - Bologna:

Medimond, 2015. - ISBN 978-88-7587-726-2. p. 55-66.

IOM: World Migration Report 2020, E-ISBN 978-92-9068-789-4, https://publications.iom.int/books/world-migration-report-2020

Kahn, R., Whited, T., M. 2018. Identification Is Not Causality, and Vice Versa, Review of Corporate Finance, Oxford University Press, 7(1), 1-21. ISSN 2046-9128, EISSN 2046-9136

Kosten, D.2018: International Migration Forum, Immigrants as Economic Contributors: They Are the New American Workforce, https://immigrationforum.org/article/immigrants-as-economic-contributors-they-are-the-new-americanworkforce/

Kováč, M. 2015. Citizens' security as life quality development factor in selfgovernment regions. In: Drivers for Progress in the Global Society : The 3rd European Interdisciplinary Forum 2015, Vilnius June 18-19 2015. - Bologna : Medimond, 2015. - ISBN 978-88-7587726-2. - S. 55-66.

Majeed, M., T. 2016. Migrant remittances and corruption: An Empirical Analysis, Pakistan Journal of Applied Economics, Applied Economics Research Centre, 26(1), 15-41, ISSN 2519-043

Meyera, D., Sherab, A. 2016. The impact of remittances on economic growth: An econometric model, EconomiA https://doi.org/10.1016/j.econ.2016.06.001 ISSN: 1517-7580

Muhammad, A., Sallahuddin, H., Khairuzzaman, K. 2013. Corruption, workers remittances, FDI and economic growth in five South and South East Asian countries: A panel data approach, Journal of Scientific Research, ISSN 1990-9233 http://www.idosi.org/mejsr/mejsr.htm

Nita, G. 2018. Remittances from Migrant Workers and their Importance in Economic Growth, International Journal of Academic Research in Accounting, Finance and Management Science http://dx.doi.org/10.6007/IJARAFMS/v8-i1/4041 ISSN: $2225-8329$

OECD: Is Migration Good for Economy?, Migration Policy Debates, www.oecd.org/migtaion

Panizza, U., Presbytero, A. 2014. Public debt and economic growth: Is there a causal effect?, Journal of Macroeconomics, 41, 21-41. ISSN 0164-070

Penn Wharton University. 2016. The effects of Immigration on the United States'economy, https://budgetmodel.wharton.upenn.edu/issues/2016/1/27/the-effects-of-immigration-on-the-united-states-economym

Pooley, C. 2019. Newspaper Reporting of Migrants in England 1851-1911. 2019. Spatial and Temporal Perspective, Journal of Migration History https://brill.com/view/journals/jmh/5/1/article-p31_31.xml

Rauser, G., et al. 2018. Migrant remittances and their impact on the economic development of the Baltic States, Geographica Pannonica, ISSN 0354-8724 (hard copy) | ISSN 1820-7138 (online)

Simonescu, M. 2019. European economic integration and migration in Romania, Economic Research-Ekonomska Istraživanja, 32(1). 36073626, https://doi.org/10.1080/1331677X.2019.1674176 Print ISSN: 1331-677X Online ISSN: 1848-9664

Sobiech, I. 2019. Remittances, finance and growth: Does financial development foster the impact of remittances on economic growth?, ScienceDirect, 113, 44-59 https://doi.org/10.1016/j.worlddev.2018.08.016 ISSN: 0305-750X

Tyburski, M., D. 2014. Curse or Cure? Migrant remittances and corruption, The Journal of Politics, 76(3), 814-824. https://www.jstor.org/stable/10.1017/s0022381614000279, ISSN: 00223816, EISSN: 14682508

Vaysilova, E.,2019. Entrepreneurship and evaluation of entrepreneurial risk through the sensitivity analysis method, The $24^{\text {th }}$ International Scientific Conference, Crisis situations solution in the specific environment, $22^{\text {nd }}$ and $23^{\text {rd }}$ may 2019, Zilina, Slovakia, ISBN 978-80-5541559-8

World Bank. 2016. Migration and Remittances Factbook, e-ISBN: 978-1-4648-0320-8, 
ENTREPRENEURSHIP AND SUSTAINABILITY ISSUES

ISSN 2345-0282 (online) http://jssidoi.org/jesi/

2020 Volume 8 Number 2 (December)

http://doi.org/10.9770/jesi.2020.8.2(37)

Make your research more visible, join the Twitter account of ENTREPRENEURSHIP AND SUSTAINABILITY ISSUES: @Entrepr69728810

World Bank. 2016. Migration and Remittances, World Bank Group, www.KNOMAD.org

World Bank. 2019. Migration and Development Brief 31,

World Bank: Press Release 2019/148

\section{Acknowledgements}

The paper is the output of a scientific project IGA 3/2019 „Creation of a mechanism for the purposes of migration to the social and economic development of the territory" (Funder: VSEMvs IGA VSEMvs, i.e. School of Economics and Management in Public Administration)

Ladislav KABÁT. Professor, his field is social statistics and quantitative analysis with special interest in data collection, data processing and data quality. In past, he held positions - Director of Statistics Division of the FAO UN in Rome, Member of the EU Statistical Advisory Committee. Participated in various projects oriented on building and strenthening the statistical systems in developing countries.

Researcher ID: https://orcid.org/0000-0001-9459-7968

ORCID ID: $\underline{\text { https://publons.com/researcher/2505141/ladislav-kabat/ }}$

Luboš CIBÁK, Assoc. prof. Ing. PhD. MBA is Chairman of the Management Board of the School of Economics and Management in Public Administration in Bratislava, Slovak Republic and head of Department of the Managerial Informatics. His research and publication activities are focused on management, informatics systems, investment protection and business law.

ORCID ID: https://orcid.org/0000-0003-3881-7924

Stanislav FILIP, Assoc prof. Ing. PhD. is the Vice-Rector for foreign affairs an teacher of the School of Economics and management in Public Administration in Bratislava. His text books, monographs and scientific papers deal with the Risk and crisis managemtn in public sector, international crisis management and public administration at the national and EU level. He is succesfull leader and manager of the several scientific projects with support from the EU structural funds. He also organise and control international colaboration and Erasmus plus program with the high educational and research institutions in abroad.

Researcher ID: F-7984-2017

ORCID ID: https://orcid.org/0000-0003-3000-9383

Copyright (C) 2020 by author(s) and VsI Entrepreneurship and Sustainability Center

This work is licensed under the Creative Commons Attribution International License (CC BY).

http://creativecommons.org/licenses/by/4.0/

C) (i) Open Access 